\title{
Mniejszości narodowe w Polsce - zarys historyczno-prawny
}

\section{Wprowadzenie}

Historia i procesy migracji ludności zadecydowały o wielonarodowości współczesnych państw. Osoby opuszczające swój kraj i osiedlające się w innym przez dłuższy czas, świadome swej odrębności narodowej i kulturowej i utożsamiające się z narodem we własnym państwie, obejmuje się terminem mniejszość narodowa. Jeśli osoby mają świadomość wspólnoty etnicznej i nie utożsamiają się z narodem we własnym państwie, tworzą mniejszość etniczną. Ochrona praw tych mniejszości wynika z prawa każdego człowieka do zachowania tożsamości i godności. Napływ obcych nie ominął też Polski, która od wieków była krajem zamieszkiwanym przez różne grupy narodowościowe. W okresie Polskiej Rzeczypospolitej Ludowej (PRL) władze zrezygnowały z wielokulturowości na rzecz państwa jednolitego etnicznie. Po 1989 r. Polska powróciła do idei państwa tolerancyjnego, przyjmując za podstawowy cel polityki wobec mniejszości zachowanie i rozwój ich tożsamości narodowej i etnicznej, co znajduje swój wyraz w prawie. Utrzymanie tożsamości mniejszości zależy też od czynników pozainstytucjonalnych, od sytuacji politycznej i demograficznej oraz indywidualnych postaw członków mniejszości. Celem artykułu jest przedstawienie rozwoju regulacji prawnych dotyczących mniejszości w Polsce od 1918 r. na tle wydarzeń historycznych i ich ocena z punktu widzenia ochrony praw jednostki i priorytetu polityki państwa polskiego wobec mniejszości narodowych i etnicznych. 


\section{Modele polityki wobec mniejszości narodowych w Europie}

W Europie mieszka około 280 mniejszości narodowych o zróżnicowanej wielkości ${ }^{1}$. W Unii Europejskiej co ósmy jej mieszkaniec należy do mniejszości, a mimo to nie ma w niej jednolitego standardu ochrony grup mniejszościowych, przez co państwa członkowskie mogą swobodnie kształtować swą politykę wobec zamieszkałych na ich terytorium mniejszości. Ułatwił im to art. 27 Międzynarodowego Paktu Praw Obywatelskich i Politycznych ONZ z dnia 16 grudnia 1966 r., w myśl którego „W państwach, w których istnieją mniejszości etniczne, religijne lub językowe, osoby należące do tych mniejszości nie mogą być pozbawione prawa do własnego życia kulturalnego, wyznania i praktykowania własnej religii oraz do posługiwania się własnym językiem"2. Sformułowanie „państwa, w których istnieją mniejszości etniczne, religijne lub językowe" niektóre kraje potraktowały jako możliwość swobodnego ich uznania i zaprzeczyły istnieniu mniejszości na swym terytorium, a co za tym idzie, nie mają stosownych regulacji. Tak postąiły Francja, Szwecja i Grecja ${ }^{3}$. We Francji formalnie nie występują mniejszości, gdyż uznaje się tam każdego obywatela francuskiego urodzonego we Francji za Francuza ${ }^{4}$. Artykuł 27 zmienił też podejście do ochrony praw mniejszości jako grupy na rzecz ochrony praw osób należących do grupy, co argumentowano tym, że podmiotem prawa jest osoba fizyczna, a nie grupa osób 5 .

Brak unormowań krajowych może też wynikać z niechęci wobec obcych grup narodowych. Grecy są niechętni Macedończykom i Turkom, Estończycy Rosjanom, a Słowacy Węgrom i Romom. Na drugim biegunie są kraje, które szczegółowo uregulowały prawa mniejszości

${ }^{1}$ Kwestie narodowościowe w Europie Środkowo-Wschodniej, t. 1, pod red. R. Zenderowskiego, J. Pieńkowskiego, Warszawa 2014, s. 136.

${ }^{2}$ Dz.U. 1977 Nr 38, poz. 167, Załącznik.

${ }^{3}$ S. Maksimiec, Mniejszości narodowe i etniczne w krajach Europy Środkowej i Wschodniej po przystapieniu do Unii Europejskiej, Warszawa 2012, s. 12. W prawie francuskim nie występuje pojęcie "mniejszości narodowe i etniczne", a narodowość jest utożsamiana z obywatelstwem. Oznacza to, że jeżeli ktoś jest obywatelem Francji, jest również Francuzem.

${ }^{4}$ T. Białek, Międzynarodowe standardy ochrony mniejszości narodowych i ich realizacja na przykładzie Białorusi, Litwy i Ukrainy, Warszawa 2008, s. 26.

${ }^{5} \mathrm{G}$. Janusz, Definiowanie mniejszości w dokumentach międzynarodowych i aktach prawa wewnętrznego, Annales Universitatis Mariae Curie-Skłodowska, Sectio K, 2008, vol. XV, 2, s. 98. 
narodowych i dały ich definicję, co ułatwia grupom obcych osób w państwie ubieganie się o status mniejszości. Tak jest w Polsce, Austrii, Belgii, Holandii, na Łotwie, Litwie, Białorusi, Ukrainie i na Węgrzech. Odmienność podejścia wynika z dwóch głównych przyczyn - wielkości obcych grup mieszkających w kraju oraz jego atrakcyjności dla imigrantów. Im grupa liczniejsza, tym silniejsze są obawy utraty własnej tożsamości narodowej, co prowadzi do rygorystycznego prawa. Tak jest w krajach nadbałtyckich, zamieszkałych przez Rosjan. Na Łotwie stanowią oni 41,5\% ogółu ludności, a w Estonii ponad 25\%. Litwa i Łotwa, korzystając z zasady samostanowienia na własnym obszarze, wprowadziły ustawę o obywatelstwie i języku dyskryminującą mniejszość rosyjskojęzyczną, którą uznaje się za zagrożenie dla integralności terytorialnej i tożsamości tych państw ${ }^{6}$. Z kolei państwa atrakcyjne dla imigrantów, jak Niemcy, Wielka Brytania, Hiszpania, Włochy i Grecja, z obawy o zdominowanie narodowej kultury przez kulturę imigrantów, narzucenie sobie obcej religii, zwyczajów, a nawet prawa, utrudniają grupom migrantów nabycie statusu mniejszości narodowej ${ }^{7}$. Natomiast kraje Europy Środkowo-Wschodniej, w których odsetek migrantów jest niski, mają liberalne ustawodawstwo, zapewniające mniejszościom szeroką ochronę. W tych państwach mniejszości narodowe, niezależnie od ich wielkości, są grupami autochtonicznymi (historycznymi), a nie imigranckimi, co w sposób zasadniczy odróżnia je od mniejszości narodowych występujących w krajach Europy Zachodniej, które wywodzą się najczęściej z grup imigrantów, słabo zintegrowanych ze społeczeństwem ${ }^{8}$. Europa Zachodnia obecnie przeżywa kryzys imigracyjny spowodowany napływem ogromnej liczby (ponad jednego miliona) uciekinierów z krajów muzułmańskich, do czego nie była przygotowana. Do uciekających przed wojną z Syrii dołączyła ludność z innych państw Afryki i Azji, a wśród niej znaleźli się terroryści z tzw. Państwa Islamskiego (ISIS), co pogłębia niechęć Europejczyków do przybyszów.

${ }^{6}$ Polityka i mniejszości narodowe na pograniczach, pod red. M. Giedrojć, M. Mieczkowskiej, J. Mieczkowskiego, Rozprawy i Studia (DCXLI), Uniwersytet Szczeciński, Szczecin 2005, s. 10.

${ }^{7}$ J. Błuszkowski, Stereotypy narodowe w świadomości Polaków. Studium socjologiczno-politologiczne, Warszawa 2003, s. 95.

${ }^{8}$ B. Berdychowska, Uwarunkowania historyczne i prawne oraz obecność w mediach problematyki mniejszości narodowych i etnicznych w Europie Środkowo-Wschodniej, w: Mniejszości narodowe i etniczne a media elektroniczne. Białoruś, Estonia, Litwa, Łotwa, Polska, Ukraina, pod red. A. Sadowskiego, T. Skoczka, Białystok 2001, s. 13. 


\section{Mniejszości narodowe w Polsce w okresie międzywojennym}

W okresie międzywojennym Polska była krajem wielonarodowym, w którym mieszkały grupy ludności tworzące mniejszości autochtoniczne (historyczne) oraz napływowe. Obecność pierwszych wynikała ze wspólnej historii Polski i krajów sąsiednich, tworzących Rzeczpospolitą Obojga Narodów, natomiast drugich była skutkiem prześladowań politycznych bądź religijnych (jak przybyłych z Czech husytów czy rosyjskich staroobrzędowców). Mniejszości przed wojną stanowiły prawie 1/3 ogółu ludności (31\% w 1934 r. $)^{9}$, co wyróżniało Polskę nawet wśród krajów Europy Środkowo-Wschodniej, w dużym stopniu zamieszkałych przez mniejszości ${ }^{10}$. W wielu regionach Polski osoby o obcych korzeniach stanowiły większość mieszkańców. Po I wojnie światowej ochronę tym grupom zapewniał podpisany przez II Rzeczpospolitą Polską tzw. mały traktat wersalski (o ochronie mniejszości), który w art. 93 ust. 1 stanowił, że Polska przyjmuje postanowienia, które główne mocarstwa sprzymierzone i stowarzyszone uznają za konieczne dla ochrony interesów mieszkańców różniących się od większości ludności rasą, językiem lub religią i godzi się na zamieszczenie tych postanowień $\mathrm{w}$ traktacie $\mathrm{z}$ tymi mocarstwami ${ }^{11}$. Traktat był jednym $z$ wielu zawartych przez zwycięskie mocarstwa Ententy z nowo powstałymi państwami. Traktaty nakładały obowiązek ochrony mniejszości jedynie na małe państwa (Polskę, Rumunię, Jugosławię, Grecję, Bułgarię, Turcję, Węgry i Czechosłowację), nie obejmując nim mocarstw, co umożliwiło Niemcom ingerencję w politykę wewnętrzną Polski $^{12}$.

${ }^{9}$ Na 32 mln ludności Polaków było 20,6 mln. Co trzeci obywatel Polski nie miał polskiego pochodzenia. Z $27 \mathrm{mln}$ obywateli polskich ponad $8 \mathrm{mln}$ deklarowało przynależność do innych grup narodowych, zob. M. Zybura, Niemcy w Polsce, Wrocław 2001, s. 145.

${ }^{10}$ P. Wróblewski, Mobilizacja i konflikt etniczny. Miejsca święte mniejszości narodowych $w$ Polsce, Warszawa 2007, s. 11.

11 Traktaty stwarzały sytuację o charakterze nierównoprawnym, gdyż obowiązek ochrony mniejszości narodowych został narzucony krajom mniejszym, z wykluczeniem mocarstw, np. Niemiec, choć zamieszkiwali je w znacznej liczbie Polacy, zob. A. Garlicki, Drugiej Rzeczypospolitej początki, Wrocław 1999, s. 93-94.

12 Polska została zmuszona do podpisania małego traktatu, będącego integralną częścią traktatu wersalskiego. Stało się to z inicjatywy Niemiec, które obawiając się 
Prawa mniejszości zostały potwierdzone w Konstytucji marcowej z 1921 r. Już w preambule została zawarta zasada równości wszystkich obywateli Rzeczypospolitej, rozwinięta w dalszej części Konstytucji ${ }^{13}$. Mniejszościom zapewniono ochronę życia, wolności i mienia (art. 95), prawo do równości i równego traktowania przed urzędami (art. 96), prawo do zakładania stowarzyszeń dobroczynnych, religijnych i społecznych (art. 110), a także wolność sumienia i wyznania (art. 111) ${ }^{14}$. W myśl art. 109 każdy obywatel miał prawo do „zachowania swej narodowości i pielęgnowania swojej mowy i właściwości narodowych", co miały regulować inne ustawy.

Na przeszkodzie realizacji tej konstytucji stanęło wiele okoliczności. Pojawiła się konieczność unifikacji prawa obowiązującego w trzech zaborach, która zakończyła się dopiero w 1931 r., wraz ze zniesieniem wszelkiego rodzaju dyskryminacji. Nadto zła sytuacja gospodarcza i wysokie bezrobocie wywoływały niechęć Polaków wobec mniejszości ${ }^{15}$, a ustalone po I wojnie światowej granice państw w Europie i zamieszkujące na ich terytorium mniejszości stały się zarzewiem wewnętrznych konfliktów narodowościowych, które przeniosły się na poziom sporów między państwami ${ }^{16}$. Ważne były też względy ideologiczne. Polacy po odzyskaniu w 1918 r. niepodległości pragnęli wskrzesić potęgę państwa polskiego z przeszłości i łatwo akceptowali myśl narodową ${ }^{17}$. Największy

odwetu za germanizację prowadzoną wobec Polaków w ramach polityki Kulturkampf, chciały zapewnić prawa własnej mniejszości pozostającej pod obcym zwierzchnictwem państwowym. Traktat miał wyeliminować ucisk mniejszości i zapewnić swobodny rozwój ich kultury, zob. J. Tomaszewski, Ojczyzna nie tylko Polaków. Mniejszości narodowe w Polsce w latach 1918-1939, Warszawa 1985, s. 27-28.

${ }^{13}$ Konstytucja z dnia 17 III 1921 r. (Dz.U. Nr 44, poz. 267), dalej „Konstytucja marcowa".

${ }^{14} \mathrm{~W}$ art. 114 Konstytucji marcowej zaznaczono, że „wyznanie rzymskokatolickie, będące religią przeważającą większości narodu, zajmuje w państwie naczelne miejsce wśród równouprawnionych wyznań".

${ }^{15}$ M. Kałużny, Ochrona prawna mniejszości narodowych i etnicznych w aspekcie ich kultury i tożsamości, w: Wptyw standardów międzynarodowych na rozwój demokracji, t. 3, pod red. J. Jaskierni, Warszawa 2013, s. 476.

${ }^{16}$ M. Waldenberg, Narody zależne i mniejszości narodowe w Europie Środkowo-Wschodniej, Warszawa 2000, s. 372.

${ }^{17}$ Podatne na nią były zwłaszcza wieś i małe miasteczka borykające się z żywotnymi problemami społeczno-gospodarczymi, zob. A. Hertz, Żydzi w kulturze polskiej, Warszawa 2014, s. 6 . 
oddźwięk w społeczeństwie znalazły poglądy Romana Dmowskiego ${ }^{18}$ i marszałka Józefa Piłsudskiego ${ }^{19}$.

Trudne położenie Polski w okresie międzywojennym i istniejące zagrożenie granic doprowadziły do przyjęcia nowej konstytucji w dniu 23 kwietnia 1935 r. $^{20}$, wzmacniającej władzę prezydenta. Konstytucja zmieniła zasady współżycia mniejszości narodowych, stawiając obowiązki obywateli ponad ich prawami. Pominęła określenie "mniejszość narodowa”. W Preambule konstytucji słowo "naród” celowo zostało zastąpione określeniem „obywatele polscy”, by podkreślić, że jej przepisy odnoszą się również do mniejszości. Taki zabieg miał ułatwić ich asymilację. $W$ art. 1 podkreślano, że państwo polskie jest dobrem wszystkich obywateli, którzy na mocy art. 6 zostali zobowiązani do lojalności wobec niego i rzetelnego wykonywania swych obowiązków, a ich prawa publiczne uzależniono od wartości ich wysiłku i zasług na rzecz dobra powszechnego (art. 7 ust. 1$)^{21}$. Konstytucja stanowiła, że państwo dąży do zespolenia wszystkich obywateli w harmonijnym współdziałaniu na rzecz dobra powszechnego (art. 9), a żadne działanie nie może stanąć w sprzeczności z celami państwa (art. 10 ust. 1). W razie oporu państwo stosuje środki przymusu (art. 10 ust. 2). W ten sposób konstytucja zakazywała mniejszościom działalności, które mogłyby godzić w interes

${ }^{18}$ R. Dmowski wyszedł z założenia o nadrzędności narodu polskiego i jego interesu nad innymi narodowościami i głosił, że „W przyszłym państwie polskim rolę właściwego suwerena pełnić miał naród polski, wyłączny dysponent zasobów gospodarczych kraju i własnego dziedzictwa kulturowego. Inne narodowości mają podporządkować się politycznej, ekonomicznej i kulturalnej dominacji Polaków" (J. Tomaszewski, Mniejszości narodowe w Polsce w latach 1918-1939, Warszawa 1985, s. 181). Roman Dmowski, twórca Narodowej Demokracji, autor m.in. prac Myśli nowoczesnego Polaka, Polityka polska i odbudowanie państwa polskiego, Kościót, naród, państwo, Świat powojenny i Polska.

${ }^{19}$ Marszałek Józef Piłsudski był zwolennikiem przesunięcia polskiej granicy jak najdalej na wschód i utworzenia pod przywództwem Polski państwa federacyjnego z Ukraina, Litwą i z Białorusią, by oddzielić Polskę od bolszewickiej Rosji i zapobiec odegraniu przez Moskwę przewodniej roli wśród narodów słowiańskich, w której widział Polskę. Piłsudski był autorem m.in. pracy Rosja. Jak stałem się socjalista. Polityka walki czynnej. Rok 1920, zob. M. Marszał, „Kwestia ukraińska” w myśli politycznej Mariana Ursyna Zdziechowskiego (1918-1939), „Wrocławsko-Lwowskie Zeszyty Prawnicze” 2014, z. 5, pod red. A. Bojki, M. Marszała, s. 31.

${ }^{20}$ Dz.U. Nr 30, poz. 227.

${ }^{21}$ Wdrożono też Program Wzmocnienia Polskości (1936-1939), który za nielegalne uznawał prowadzenie działalności społecznej, kulturalnej i politycznej przez mniejszości, zob. A. Kupczyk, Z badań nad polityka państwa polskiego wobec mniejszości narodowych i etnicznych po odzyskaniu niepodległości 11 XI 1918 r., http://www.bibliotekacyfrowa.pl/ Content/51958/08_Adam_Kupczyk.pdf (dostęp: 22 X 2016). 
II RP. Przyznawała im także pewne prawa, wyrażone w art. 5 ust. 2, który stanowil, że „Państwo zapewnia obywatelom możliwość rozwoju ich wartości osobowych oraz wolność sumienia, słowa i zrzeszeń". Z kolei art. 7 ust. 2 zawierał klauzulę antydyskryminacyjną, zgodnie z która pochodzenie, wyznanie, płeć ani narodowość nie mogą być powodem ograniczenia uprawnień publicznych ${ }^{22}$.

Mniejszości na Kresach Wschodnich dążyły do stworzenia własnego państwa, domagając się autonomii, a ich integrowaniu się z Polakami nie służyło wychowanie młodzieży mniejszości na patriotów i dobrych obywateli II Rzeczypospolitej Polskiej ${ }^{23}$. Wzajemne stosunki Polaków i mniejszości można określić jako złe.

Ukraińcy zamieszkujący w liczbie 5145 tys. (16\% ludności) Kresy Południowo-Wschodnie byli niechętni Polsce i Polakom ze względu na istniejącą tam w latach 1918-1919 Zachodnioukraińską Republikę Ludową, traktowaną jako enklawa państwowości ukraińskiej. Wrogość wobec Polaków podsycała Organizacja Ukraińskich Nacjonalistów (OUN), nawołująca do walki przeciw Polakom. Nacjonaliści przekonywali, że Ukraina padła ofiarą oszustwa Europy, która odebrała jej Galicję Wschodnią i przekazała Polsce. Odrzucali możliwość życia w Polsce ${ }^{24}$ na rzecz utworzenia niepodległej i suwerennej Ukrainy, obejmującej część ziem polskich ${ }^{25}$. Mniejszość ukraińska pozbawiona perspektyw zawodowych ${ }^{26}$ uznawała władze polskie za przejściowe i okupacyjne. Między OUN a władzami polskimi toczyła się walka o świadomość ludzi żyjących na Wschodzie, których władze polskie starały się zasymilować ${ }^{27}$.

Równie nieufni wobec Polaków byli Białorusini, stanowiący 6\% ogółu mieszkańców Polski (1966 tys.), obawiający się wynarodowienia i unicestwienia języka białoruskiego na skutek przesiedleń Polaków na

${ }^{22}$ W. Szwajko, Rosyjska mniejszość narodowa w Polsce w latach 1921-1939. Stan prawny i działalność społeczno-polityczna, w: Śladami Rosjan w Polsce, Warszawa 2013, s. 97. Artykuł 81 stanowił powtórzenie art. 109 Konstytucji marcowej.

${ }^{23}$ Przewidywała je ustawa o szkolnictwie, co stało się źródłem wielu konfliktów.

${ }^{24} \mathrm{~J}$. Radziejowski, Kształtowanie się oblicza ideowego radykalnego nacjonalizmu ukraińskiego (1917-1929), w: Polska - Polacy-mniejszości narodowe, pod red. E. Łuczyk-Grześkowiak, Wrocław-Warszawa-Kraków 1992, s. 317.

${ }^{25}$ W.A. Serczyk, Polaków sprawy ukraińskie, w: Polska - Polacy..., s. 296.

${ }^{26}$ Rozpisywano się o tym, że szanse kariery zawodowej i awansu społecznego dla Ukraińców z wyższym wykształceniem są minimalne i po studiach najczęściej wracają oni na wieś.

${ }^{27}$ J. Tomaszewski, Ojczyzna nie tylko Polaków..., s. 55, 79. 
ich tereny. Głównym zajęciem Białorusinów było rolnictwo, w którym własność skoncentrowana była w rękach Polaków, co Białorusini uznali za przyczynę swej biedy ${ }^{28}$. Jej wyeliminowanie łączyli z podziałem wielkich majątków ziemskich, na co nie było zgody państwa polskiego. Białorusini rozczarowani postawą Polski dostrzegli w Niemczech i w Rosji swych głównych protektorów, a do Rosji chcieli nawet przyłączyć zamieszkiwany przez siebie obszar.

Stosunki polskie z mniejszością litewską (ok. 200 tys. osób) nieliczną, ale bardzo radykalna, a przez to stwarzającą wiele problemów, były niezwykle napięte, zwłaszcza po przyłączeniu Wilna do Polski ${ }^{29}$. Litwini ignorowali polskie władze, warunkując normalizację wzajemnych stosunków zwrotem Wilna i uznaniem niepodległej Litwy, co Polska odrzuciła ${ }^{30}$.

Sprawy mniejszości niemieckiej mieszkającej w Polsce w liczbie 744 tys. osób (2,3\% ogółu ludności) zaogniały stosunki polsko-niemieckie. Mniejszość uzyskała wsparcie moralne i przede wszystkim finansowe Republiki Weimarskiej i była traktowana jako istotny argument za rewizją granic ustalonych po I wojnie światowej ${ }^{31}$. W latach 1919-1925, poddana silnej nacjonalistycznej indoktrynacji, żądała powrotu zamieszkiwanych przez siebie ziem do Niemiec ${ }^{32}$. W okresie poprzedzającym wybuch II wojny światowej przygotowywano młodzież niemiecką

28 92\% Białorusinów żyło z ziemi, z czego aż 89\% stanowili właściciele drobnych gospodarstw, zob. J. Tomaszewski, Studia nad najnowszą historią Białorusinów w Polsce, w: Polska-Polacy..., s. 225.

${ }^{29}$ Dla Litwinów Wilno było stolicą państwa litewskiego, wspaniałym miastem z bogatą historią i legendarnymi władcami, zob. J. Tomaszewski, Ojczyzna nie tylko Polaków..., s. 155.

${ }^{30}$ D. Hejwosz-Gromkowska, Swoi i obcy w Drugiej Rzeczpospolitej-sytuacja mniejszości narodowych. Próba zarysowania problemu, http://liberte.pl/swoi-i-obcy-w-drugiej-rzeczpospolitej-sytuacja-mniejszosci-narodowych-proba-zarysowania-problemu/ (dostęp: 5 IX 2016). Mniejszość litewska popierała postulaty Litwinów domagających się ziemi wileńskiej z Wilnem oraz północnej Suwalszczyzny. Podobne żądania zgłaszali działacze białoruscy, uznający Wileńszczyznę za własną.

${ }^{31} \mathrm{~W}$ tym czasie ukazywały się liczne prace publicystów niemieckich opisujące rzekomy ucisk Niemców w Polsce, co pogarszało stosunki z państwem niemieckim, zob. Polska-Polacy..., s. 31.

${ }^{32}$ P. Hauser, Mniejszość niemiecka w Polsce w latach 1918-1939, w: Polska - Polacy..., s. 32, 40. Niemcy rozpowszechniali pogląd, jakoby ziemie zachodnie upadły pod polskim panowaniem, a niemiecka prasa utwierdzała swych czytelników w przekonaniu, że utracone tereny są częścią całości, zostały oderwane od swej macierzy i stanowią „wiecznie krwawiącą ranę", zob. D. Matelski, Niemcy w Polsce w XX wieku, Warszawa-Poznań 1999, s. 131. 
do wojny, organizując dla niej ćwiczenia wojskowe i sprawnościowe ${ }^{33}$. Polacy traktowali Niemców nieufnie i starali się upowszechniać polską kulturę na obszarach zamieszkiwanych przez nich ${ }^{34}$.

Mniejszość rosyjską (od 100 do 200 tys.) tworzyli głównie mieszkańcy byłego zaboru rosyjskiego. Ich liczba w okresie międzywojennym malała ${ }^{35}$, gdyż większość Rosjan powracała w głąb imperium, nie dostrzegając perspektyw na pomyślne życie w Polsce $^{36}$. Pozostali szybko się polonizowali i nie stwarzali poważniejszego problemu politycznego. Na południu Czesi i Słowacy dążyli do zjednoczenia z Czechosłowacją i popierali polityków postulujących plebiscyty w sprawie aneksji terytorialnej. Odmawiali płacenia podatków w Polsce i pełnienia służby wojskowej, a nazywanie ich Polakami uważali za obraźliwe ${ }^{37}$. Ze względu na istniejące zagrożenie odłączenia się rejony te były obsadzane wojskiem polskim ${ }^{38}$.

10\% ludności Polski stanowiła mniejszość żydowska (3133 tys. osób), uchodząca za majętną. Żydzi dochodzili do wysokich stanowisk publicznych, zajmowali się przemysłem i handlem, konkurując często z polskimi przedsiębiorcami. Przejawem niechęci Polaków wobec nich były bezpodstawne oskarżenia o mordy rytualne i przestępstwa. Zdarzały się też rozboje i rabunki żydowskich sklepów ${ }^{39}$. Takie zachowania wynikały z panującej po wojnie społecznej demoralizacji, a także z mitu o żydowskim bogactwie i tchórzostwie ${ }^{40}$. W latach trzydziestych zasada numerus clausus ograniczyła liczbę studentów żydowskiego pochodzenia na uczelniach. Eksterminacji Żydów dokonali naziści niemieccy w okresie okupacji Polski ${ }^{41}$.

${ }^{33}$ A. Sobecka, Kalejdoskop. Spotkania z mniejszościami narodowymi, Gdańsk 2014, s. 43.

${ }^{34}$ Zamknęli m.in. 2/3 niemieckich szkół, uzasadniając to uchybieniami sanitarno-budowlanymi.

${ }^{35} \mathrm{~W}$ żadnym miasteczku i powiecie Rosjanie nie stanowili większości mogącej odegrać znaczniejszą rolę, zob. J. Tomaszewski, Ojczyzna nie tylko Polaków..., s. 148.

${ }^{36}$ M. Cybart, Rosjanie w Łodzi, w: Śladami Rosjan..., s. 21.

${ }^{37}$ J. Tomaszewski, Ojczyzna nie tylko Polaków..., s. 30.

${ }^{38}$ L. Olejnik, Czesi i Stowacy, w: Mniejszości narodowe i etniczne w Polsce po II wojnie światowej. Wybrane elementy polityki państwa, pod red. S. Dudry, B. Nitschke, Kraków 2010, s. 183.

${ }^{39}$ A. Indraszczyk, Dzieje ziemi łosickiej. Z historii mniejszości narodowych, kulturowych i religijnych, Warszawa-Łosice 2010, s. 23.

${ }^{40} \mathrm{~J}$. Tomaszewski, Społeczność żydowska a Polacy w II Rzeczypospolitej. Polska myśl polityczna XIX i XX wieku, w: Polska - Polacy..., s. 113.

${ }^{41} \mathrm{~B}$. Klimkiewicz, Mniejszości narodowe w sferze publicznej, reprezentacje, praktyki i regulacje medialne, Kraków 2003, s. 79. 


\section{Polityka PRL wobec mniejszości narodowych}

Po zakończeniu II wojny światowej polityka Polski wobec mniejszości była kształtowana przez wiele czynników. Najważniejsze z nich to: postanowienia konferencji w Jałcie i Poczdamie o zmianie granic i łączące się z tym ruchy ludności, znaczny ubytek ludności na skutek holocaustu i zbrodni ludobójstwa dokonanych przez Niemców po 1 września 1939 r., wpływ polityczny ZSRR i wprowadzenie ustroju socjalistycznego, dążenie władzy do stworzenia z Polski państwa jednolitego etnicznie ${ }^{42}$, a także stosunkowo późne przyjęcie międzynarodowych standardów ochrony mniejszości narodowych.

Na mocy postanowień konferencji w Poczdamie Niemcy musieli opuścić tereny przyznane Polsce. W odwecie za agresję III Rzeszy i dokonane zbrodnie ludobójstwa państwo polskie stosowało wobec nich surowe represje. Na mocy dekretów z 1946 r. Niemcy najpierw zostali pozbawieni majątków ${ }^{43}$, a następnie utracili pełnię praw obywatelskich ${ }^{44}$. W wyniku masowych przesiedleń prowadzonych do 1950 r., obejmujących nawet 4,5 mln ludności niemieckiej, pozostało zaledwie 200 tys. Niemców, będących wysoko wykwalifikowanymi fachowcami, niezbędnymi do odbudowy zniszczonej wojną Polski ${ }^{45}$. Byli oni dyskryminowani na rynku pracy, w zakresie wynagrodzenia i awansu, mieli też ograniczoną możliwość codziennych zakupów. Ich imiona i nazwiska były polonizowane. Zmiana polegała na dosłownym tłumaczeniu (np. Adler po zmianie to Orłowski), na dodaniu polskiej końcówki (np. Walling po zmianie to Waliński) lub powrocie do nazwisk polskich przodków i krewnych. Imiona negatywnie kojarzone przez Polaków (Adolf, Rudolf, Wilhelm, Ferdynand) zostały zmienione ${ }^{46}$. Niszczono

42 J. Wasilewski, Współczesne społeczeństwo polskie. Dynamika zmian, Warszawa 2006, s. 429. Zasadniczo taki charakter Polska zachowała do dziś.

${ }^{43}$ Na mocy Dekretu z dnia 8 III 1946 r. o majątkach opuszczonych i poniemieckich (Dz.U. Nr 13, poz. 87 i Dz.U. 1946 Nr 28, poz. 182).

${ }^{44}$ Na mocy art. 45 Dekretu z dnia 13 VI 1946 r. o przestępstwach szczególnie niebezpiecznych w okresie odbudowy państwa (Dz.U. Nr 30, poz. 192) w związku z planowanym przesiedleniem obowiązywał Niemców zakaz nabywania, sprzedawania, ukrywania i niszczenia posiadanego mienia.

${ }^{45}$ A. Szczepański, Aktywność społeczno-polityczna mniejszości niemieckiej na Śląsku Opolskim po 1989 roku, Toruń 2013, s. 73. Wykwalifikowanych Niemców angażowano do pracy m.in. w Wałbrzyskim Zagłębiu Węglowym, w Żegludze Odrzańskiej i w państwowych gospodarstwach rolnych, zob. M. Zybura, op. cit., s. 207.

${ }^{46}$ Z. Czarnuch, Oswajanie krajobrazu. Polscy osadnicy w dorzeczu dolnej Warty, w: Wokót niemieckiego dziedzictwa kulturowego na Ziemiach Zachodnich i Pótnocnych, pod red. Z. Mazura, Poznań 1997, s. 181. 
najdrobniejsze oznaki niemieckości ${ }^{47}$, a miejscowości i ulice otrzymywały polskie nazwy, by przypomnieć o piastowskim charakterze odzyskanych ziem ${ }^{48}$. Do 1949 r. słowo Niemcy było pisane małą literą ${ }^{49}$. Po zakończeniu wysiedleń władze w ograniczonym zakresie zezwoliły Niemcom na działalność kulturalno-oświatową i społeczną, zawieszoną po ponownych masowych ich wyjazdach, ponadto do 1989 r. na Śląsku i Opolszczyźnie obowiązywał zakaz nauki języka niemieckiego ${ }^{50}$. Aż do lat siedemdziesiątych władze polskie podsycały germanofobię, odpowiadając na rewizjonistyczne hasła pojawiające się w Niemczech, i dopiero po zmianie ustroju, w 1991 r. przyznały Niemcom mieszkającym w Polsce status mniejszości narodowej ${ }^{51}$.

Również wobec mniejszości ukraińskiej państwo polskie stosowało surowe represje ze względu na powszechnie formowany wobec Ukraińców zarzut sprzyjania Niemcom w czasie II wojny światowej i przynależności do band Ukraińskiej Powstańczej Armii (UPA), masowo mordujących Polaków na Wschodzie. We wrześniu 1944 r. została zawarta umowa między Polskim Komitetem Wyzwolenia Narodowego (PKWN) a Ukraińską Socjalistyczną Republiką Radziecką o ewakuacji obywateli polskich z terytorium Ukrainy i ludności ukraińskiej z terenów Polski, na mocy której z Polski do ZSRR wyjechało ok. 500 tys. osób. W 1947 r. władze polskie przeprowadziły „akcję Wisła”, by pod przykrywką rozprawienia się z UPA przymusowo przesiedlić Ukraińców i Łemków na Pomorze Zachodnie, Mazury i Dolny Śląsk w celu ich asymilacji z Polakami. Dla jej przyśpieszenia i zarazem uniemożliwienia kontaktów między Ukraińcami wprowadzono rygorystyczne zasady lokalizacji rodzin ukraińskich w nowym miejscu zamieszkania, m.in. określając maksymalną ich liczbę w jednej miejscowości.

47 Zgodnie z hasłem „Na ziemiach Polski ani jednego śladu niemieckiej kultury, obyczaju, języka czy pisma" niszczono książki, popielniczki, opakowania, zamalowywano napisy na murach. Karano również proniemieckie zachowania, za które uchodziło obchodzenie urodzin, zamiast zgodnych z polską tradycją imienin, zob. M. Świder, Odniemczanie dla każdego, http://www.nto.pl/wywiady/art/3989961,odniemczanie-dla-kazdego,id,t.html (dostęp: 22 X 2016).

${ }^{48}$ M. Wagińska-Marzec, Ustalanie nazw miejscowości na Ziemiach Zachodnich i Pótnocnych, w: Wokót niemieckiego dziedzictwa kulturowego..., s. 374-376. Nazwę Grünberg zmieniono na Zielona Góra, Kreuzburg na Kluczbork, Hirschberg na Jelenia Góra, Gartenstrasse na ul. Ogrodowa.

${ }^{49}$ M. Zybura, op. cit., s. 207.

${ }^{50}$ A. Malicka, Ochrona mniejszości narodowych. Międzynarodowe standardy i rozwiązania polskie, Wrocław 2004, s. 103-104.

${ }^{51}$ Na mocy Traktatu z dnia 17 VI 1991 r. o dobrym sąsiedztwie i przyjaznej współpracy między Polską a Niemcami (Dz.U. 1991 Nr 14, poz. 56). 
Ukraińcy obarczani zbiorową odpowiedzialnością za mordy na Polakach byli dyskryminowani. Marginalizowano ich język i tradycje, przez co kultura ukraińska została zamknięta w domach, a Ukraińcy udawali Polaków ${ }^{52}$.

Wieloletni spór o Spisz i Orawę oraz poparcie przez Słowaków agresji III Rzeszy na Polskę były przyczynami niechęci polskich władz wobec mniejszości słowackiej. W odwecie za słowakizację Polaków przed wojną władze polskie po 1945 r., mimo uznania wielokulturowości ludności pogranicza, zaczęły polonizować Słowaków. Zamknęły, uruchomione na krótko, szkoły i instytucje kulturalne, a na czynny opór Słowaków odpowiedziały aresztowaniami i wprowadzeniem godziny policyjnej ${ }^{53}$. Polonizacją objęto też mniejszość czeską. Od wieków Polska i Czechy rywalizowały o Ziemię Cieszyńska, wzajemnie wynaradawiając się. Były zamykane szkoły, niszczone książki i dwujęzyczne napisy, a obywatele sąsiada mieli utrudniony awans zawodowy. Na granicy często dochodziło do potyczek.

Wrogo odnoszono się także do Litwinów, których najczęściej wbrew ich woli deportowano na podstawie analogicznej jak z Ukrainą umowy o ewakuacji (wrzesień 1944 r.). Litwini manifestowali silne przywiązanie do ziemi swego zamieszkania, określając je jako „małą Litwę” lub „małą ojczyznę ze stolicą w Puńsku". Wyjechało ich wówczas około jednego tysiąca. Sytuację komplikowały powroty Litwinów do domostw znajdujących się już w granicach Polski, ale w większości zajętych przez Polaków ${ }^{54}$. Położenie mniejszości litewskiej po wojnie zależało od sposobu traktowania Polaków na Litwie i było wypadkową stosunków, jakie istniały pomiędzy państwami ${ }^{55}$.

Również z Białorusią została podpisana umowa o wzajemnej ewakuacji obywateli (wrzesień 1944 r.). Polacy podejrzliwie odnosili się do mniejszości białoruskiej, w większym stopniu zrusyfikowanej niż spolonizowanej, co uzasadniało obawy, że w przyszłości zechce się ona przyłączyć do Związku Radzieckiego. Popierali masową emigrację

\footnotetext{
${ }^{52}$ R. Drozd, Ukraińcy w Polsce wobec swojej przeszłości (1947-2005), Słupsk 2013, s. 55.

${ }^{53}$ J. Kwiek, Z dziejów mniejszości słowackiej na Spiszu i Orawie w latach 1945-1957, Kraków 2002, s. 7-15.

${ }^{54}$ Mniejszości narodowe i etniczne w Polsce..., s. 149.

${ }^{55}$ Osobom deklarującym pochodzenie litewskie uniemożliwiano awans, np. pracę w urzędach państwowych. Mimo to Litwini nie chcieli poddać się asymilacji i polonizacji, przyjmując bierną i separatystyczną postawę wobec władz polskich i polskiego społeczeństwa, zob. H. Chałupczak, T. Browarek, Mniejszości narodowe w Polsce w latach 1918-1995, Lublin 1998, s. 209.
} 
Białorusinów na Wschód i ograniczanie ich praw, wypominając im współpracę z okupantem hitlerowskim. Polskę opuściło 34 tys. Białorusinów, a ich prawdziwym dramatem były głód i bieda ${ }^{56}$.

Choć Polska po II wojnie światowej znalazła się w orbicie wpływów ZSRR, mniejszość rosyjska nie mogła się tu swobodnie rozwijać. $Z$ wyjątkiem uprzywilejowanych wyższej rangi funkcjonariuszy pozostali Rosjanie żyli w zamkniętych enklawach, poza zainteresowaniem władz polskich i radzieckich. Zresztą te ostatnie wiernie podzielały stanowisko Stalina, że każdy Rosjanin mieszkający poza ZSRR jest zdrajcą ${ }^{57}$.

W wyniku holocaustu została zdziesiątkowana bardzo liczna przed wojną mniejszość żydowska. Pochłonął on 3,5 mln ofiar, a do ogromu tragedii Polacy odnosili się z głębokim współczuciem. W latach 1944-1950 Żydzi byli w Polsce jedyną mniejszością korzystającą z pełni praw ${ }^{58}$. Powstało wówczas m.in. kilkanaście żydowskich organizacji politycznych i komitetów terenowych wspierających lokalne wspólnoty. W 1950 r. zostało utworzone Towarzystwo Społeczno-Kulturalne Żydów, zajmujące się m.in. zaspokajaniem potrzeb kulturalnych tej społeczności, promowaniem języka jidysz, rozwijaniem twórczości literackiej, artystycznej i naukowej ${ }^{59}$. Żydzi, jako jedyna mniejszość w tym czasie, wydawali też własny tygodnik - „Fołks Sztyme” (Głos Ludu). Na mocy wspomnianych już umów PKWN z Ukraina, Litwą i Białorusią masowo osiedlali się w Polsce. Jednak ich duży udział we władzy wzbudzał niechęć wśród Polaków. W 1946 r. na tle fałszywych pomówień doszło do tzw. pogromu kieleckiego, w wyniku którego życie straciło 42 Żydów. Po tych wydarzeniach nastąpił exodus 20 tys. Żydów z Polski, w tym 1/3 mieszkających na Dolnym Śląsku. Do połowy lat pięćdziesiątych stosunki ludności

\footnotetext{
${ }^{56}$ Aparat bezpieczeństwa Polski Ludowej wobec mniejszości narodowych i etnicznych oraz cudzoziemców, pod red. J. Syrnyki, Warszawa 2009, s. 118-120. Obawa przed przymusowym wysiedleniem towarzyszyła Białorusinom przez długie lata. Chłop białoruski pragnął awansu społecznego i niejednokrotnie popierał władze komunistyczne, podejmując pracę m.in. w Urzędzie Bezpieczeństwa. Nastawiało to w jeszcze większej mierze nieprzychylnie społeczeństwo polskie względem niego, zob. K. Kakarenko, Wspótczesne stosunki polsko-białoruskie, Poznań 2013, s. 398.

${ }^{57}$ K. Loziński, Rosjanie w Polsce, http://www.kontrateksty.pl/index.php?action=show \&type $=$ news \&newsgroup $=25$ \&id=1508 (dostęp: 12 I 2017).

${ }^{58}$ E. Waszkiewicz, Powstanie i rozpad skupiska Żydów na Dolnym Śląsku (lata 1945-1968), w: Polityka i mniejszości narodowe..., s. 142.

${ }^{59}$ G. Berendt, Żydzi (do 1989 r.) w cieniu PZPR. Działalność Towarzystwa Społeczno-Kulturalnego w Polsce pod rządami komunistów (1950-1989), w: S. Dudra, B. Nitschke, Stowarzyszenia mniejszości narodowych, etnicznych i postulowanych w Polsce po II wojnie światowej, Kraków 2013, s. 171,
} 
polskiej i żydowskiej były poprawne, po czym ujawnił się antysemityzm, skutkujący nawet zamykaniem żydowskich szkół, instytucji kulturalnych i społecznych ${ }^{60}$. Rządząca Polska Zjednoczona Partia Robotnicza próbowała się temu przeciwstawić i na VIII Plenum Komitetu Centralnego w 1956 r. podjęła uchwałę o zwalczaniu nacjonalizmu i antysemityzmu wśród swych członków i decydentów, w której podkreślono swobodę obywateli wyboru narodowości i sprecyzowano prawa mniejszości (do zakładania szkół i stowarzyszeń społeczno-kulturalnych, wydawania pism i rozwijania kultury narodowej ${ }^{61}$. Zadeklarowane w uchwale swobody zaktywizowały wszystkie mniejszości narodowe, które powołały swoje stowarzyszenia i zaczęły wydawać własne tytuły prasowe (białoruska "Niwa”, ukraińskie "Nasze Słowo", słowacki „Žiwot”, litewska "Aušra”). Wolność działania była w istocie pozorna, gdyż stowarzyszenia znalazły się pod ścisłą kontrolą ministerstwa spraw wewnętrznych, a prasa była cenzurowana i ograniczona zasadą "jedna gazeta centralna dla jednej grupy narodowościowej". Zakaz pisania na tematy wrażliwe (np. akcji "Wisła") upodobnił prasę mniejszości do oficjalnych tytułów, co skutkowało pojawieniem się gazet mniejszości w drugim obiegu. Dnia 15 listopada 1956 r. weszła w życie ustawa o zmianie imion i nazwisk ${ }^{62}$, na mocy której władze rozpoczęły polonizację imion i nazwisk osób należących do mniejszości ${ }^{63}$, uznając za jej przesłankę ich niepolskie brzmienie (art. 2 ust. 2 tejże ustawy). Polonizacja była odgórna i urzędy bez zgody zainteresowanych zmieniały ich imiona i nazwiska $w$ aktach stanu cywilnego, w aktach urodzenia i przy wydawaniu dokumentów tożsamości ${ }^{64}$. Mimo że ustawa nie przewidywała kar dla sprzeciwiających się zmianie, w praktyce jednak byli oni pozbawiani kartek żywnościowych, mieli utrudniony awans zawodowy, dostęp do studiów i groziło im opuszczenie kraju ${ }^{65}$. Konstytucja Polskiej Rzeczypospolitej Ludowej z dnia 22 lipca

${ }^{60}$ E. Waszkiewicz, op. cit., s. 145.

${ }^{61}$ E. Mironowicz, Uwarunkowania polityczne rozwoju życia narodowego Białorusinów w Polsce Ludowej, w: Polska myśl polityczna XIX i XX wieku. Między Polską etniczną a historyczna, t. 6, pod red. W. Wrzesińskiego, Wrocław 1980, s. 285.

${ }^{62}$ Dz.U. 2005 Nr 233, poz. 1992.

${ }^{63} \mathrm{~J}$. Plewko, Mniejszości narodowe i etniczne oraz społeczności języka regionalnego a samorzad terytorialny w Polsce, Lublin 2009, s. 103.

${ }^{64}$ Najczęściej przesyłano zawiadomienie o zmianie imienia i nazwiska.

${ }^{65}$ M. Świder, Odniemczanie na Opolszczyźnie w latach 1945-1950 na przykładzie zmian nazwisk, http://www.google.pl/url?sa=t\&rct=j\&q=\&esrc=s\&source=web\&cd=1\&ved= 0ahUKEwiewbX4ve7PAhUGGCwKHTFIB3QQFggcMAA\&url=http\%3A\%2F\%2Fapcz. pl\%2Fczasopisma\%2Findex.php (dostęp: 22 X 2016). 
1952 r. ${ }^{66}$ pomijała istnienie mniejszości, stanowiąc o „ludzie i narodzie”. Zaledwie w dwóch artykułach odnosiła się do zróżnicowania narodowego kraju. Artykuł 69 w ust. 1 wprowadzał zasadę równych praw dla wszystkich obywateli PRL bez względu na narodowość, rasę i wyznanie we wszystkich obszarach życia, natomiast w ust. 2 stanowił, że szerzenie nienawiści lub pogardy, wywoływanie waśni lub poniżanie człowieka ze względu na różnice narodowości, rasy czy wyznania jest zakazane. $Z$ kolei zgodnie $z$ art. 81 czynne prawo wyborcze otrzymywali wszyscy, którzy ukończyli 18 lat, bez względu m.in. na przynależność narodowa, rasową i wyznanie.

Organy administracyjne zostały upoważnione do wydawania aktów wykonawczych niskiej rangi, łatwych do zmiany ${ }^{67}$. Polityka władz wobec mniejszości podporządkowana była wyzwaniu budowy państwa jednonarodowego, co realizowały kolejne rządy do 1989 r. Władze komunistyczne wyszły z założenia, że jednolitość etniczna ułatwi odbudowę silniejszej Polski i powrót do tzw. piastowskich korzeni ${ }^{68}$, a dla społeczeństwa powinna być wartością rekompensującą utratę Kresów Wschodnich. Partia przekonywała o korzyściach z przesunięcia granic, dowodząc, że Polska pozbyła się terenów będących "zarzewiem wiecznego niepokoju i wojen"69. Mniejszości były inwigilowane z obawy, że ich członkowie podejmą wrogą dla Polski współpracę z rządami swych drugich ojczyzn. Mogły prowadzić działalność folklorystyczną (występy chórów, zespołów i teatrów), władze bowiem w dążeniu, by granice Polski pokrywały się z granicami etnicznymi, planowały je spolonizować. Polityka ekskluzji etnicznej odbywała się przy poparciu społeczeństwa, które doświadczone polityką zaborców oraz kolaboracją części mniejszości w czasie II wojny światowej, przejawiało wyraźną niechęć do mniejszości (zwłaszcza niemieckiej i ukraińskiej) i skłonne było rozwijać jedynie własną narodowość ${ }^{70}$.

Rządzący wymagali od mniejszości bezwzględnej lojalności i zerwania kontaktów z państwami swego pochodzenia, o czym świadczy wypowiedź W. Gomułki na VI Kongresie Związków Zawodowych

${ }^{66}$ Konstytucja Polskiej Rzeczypospolitej Ludowej z dnia 22 lipca 1952 r. (Dz.U. Nr 33, poz. 232).

${ }^{67}$ B. Berdychowska, op. cit., s. 14.

${ }^{68}$ M. Budyta-Budzyńska, Mniejszości narodowe - bogactwo czy problem. Instytucjonalizacja mniejszości narodowych w Polsce w latach 1982-2002, Warszawa 2003, s. 18.

${ }^{69}$ E. Mironowicz, op. cit., s. 280.

${ }^{70}$ L.M. Nijakowski, Etniczność, pamięć i asymilacja. Wokót problemów zachowania tożsamości mniejszości etnicznych i narodowych w Polsce, Warszawa 2009, s. 132. 
(1967): „każdy obywatel Polski powinien mieć jedną ojczyznę - Polskę Ludową". W wyniku takiej polityki narodowość wielu grup została zamknięta w rodzinnych domach, we wspólnotach regionalnych lub kościelnych ${ }^{71}$. Władze komunistyczne zamknęły też granice Polski przed cudzoziemcami, zabraniając im wjazdu do Polski, nawet w celu odwiedzenia rodzin. Popierały natomiast emigrację mniejszości narodowych. Po 1950 r. do Republiki Federalnej Niemiec wyjechało 1,5 mln osób, które były największą grupa przybyłych tam przesiedleńców (nawet $60 \%)^{72}$. Po wydarzeniach marcowych w 1968 r., w atmosferze oskarżeń o syjonizm, odpowiedzialności za stalinizm i kryzys gospodarczy, Żydzi opuścili Polskę (15-20 tys. ${ }^{73}$. W przemówieniu na wspomnianym kongresie W. Gomułka wprost stwierdził wyobcowanie Żydów w społeczeństwie polskim i popieranie przez nich agresji Izraela na Egipt. Nie dziwi więc, że wyjeżdżający otrzymywali paszport z adnotacja, że nie są obywatelami polskimi i nie mają prawa powrotu do Polski. Powszechne było przekonanie, że emigracja Żydów jest słuszna ${ }^{74}$, ale emigracja pomarcowa utrwaliła obraz Polski jako kraju antysemickiego, w którym antysemityzm ma "głębokie korzenie i jest bardzo rozprzestrzeniony"75. Holocaust i masowa emigracja sprawiły, że Żydzi jako wielka społeczność narodowo-kulturalna odeszli w Polsce do przeszłości i dziś jedynie w muzeach można poznać ich codzienne życie ${ }^{76}$.

Władze PRL odnosiły się wrogo do innych wyznań i Kościołów. Inaczej niż w II RP, która uznawała wiele religii (współistnieli katolicy, wyznawcy prawosławia, grekokatolicy, staroobrzędowcy, luteranie, kalwini, wyznawcy judaizmu i islamu ${ }^{77}$, PRL preferowała bezwyznaniowość lub istnienie jednego Kościoła. Uderzało to w mniejszości, dla których Kościół pozostawał często jedyną ostoją ich tożsamości, a uczestnictwo w liturgii było elementem wyróżniającym pochodzenie ${ }^{78}$. Mniejszości

${ }^{71}$ S. Łodziński, Polityka wobec mniejszości narodowych i etnicznych $w$ Polsce $w$ latach 1945-2008, w: Mniejszości narodowe i etniczne w Polsce..., s. 23.

${ }_{72}$ A. Szczepański, op. cit., s. 76-78.

${ }^{73}$ A. Hertz, op. cit., s. 267.

${ }^{74}$ M. Alberska, R. Juchnowski, Polska i Polacy poza granicami kraju w polskiej polityce i myśli politycznej XX wieku, Wrocław 2006, s. 343.

${ }^{75}$ M. Waldenberg, op. cit., s. 402.

${ }^{76}$ Żydzi, którzy przeżyli holocaust, dobrowolnie opuszczali Polskę, nie mogąc „żyć na cmentarzu", zob. A. Hertz, op. cit., s. 25, 32.

77 T. Czerwiński, Polska wielu kultur i religii, Warszawa 2013, s. 5.

${ }^{78}$ P. Wróblewski, Społeczność polska w Zelowie. Problemowa monografia socjologiczna, Warszawa 1996, s. 18-19. 
zostały pozbawione dostępu do mediów publicznych, zwłaszcza radia i telewizji oraz prasy, które zmonopolizowało państwo, podporządkowując je swej polityce tworzenia państwa jednolitego pod względem etnicznym ${ }^{79}$. Od lat siedemdziesiątych władze zaczęły tolerować wystąpienia nacjonalistyczne, publikacje o charakterze dyskryminującym grupy obcego pochodzenia, profanacje obiektów sakralnych, cmentarzy, pomników należących do mniejszości i rozbiórki świątyń ${ }^{80}$. Niszczenie pamiątek odmiennych kultur wspierała propaganda usuwania z przestrzeni publicznej obiektów symbolizujących panowanie zaborców, z którymi utożsamiano mniejszości ${ }^{81}$. Nawet jeśli pojawiały się deklaracje o wspieraniu mniejszości i tolerancji, to nie szły za nimi żadne działania ${ }^{82}$.

\section{Sytuacja prawna mniejszości narodowych w Polsce po 1989 r.}

W wyniku transformacji ustroju Polski, zapoczątkowanej w 1989 r., sytuacja członków mniejszości zmieniła się diametralnie. Ważne były słowa z exposé premiera Tadeusza Mazowieckiego: „chcielibyśmy, aby czuli się tutaj jak w domu, pielęgnowali swój język, a swoją kultura wzbogacali naszą ojczyznę", które sugerowały odrzucenie dotychczasowej polityki wobec mniejszości na rzecz zachowania ich tożsamości narodowej i etnicznej. Po zakończeniu „zimnej wojny” tę zmianę było również widać na świecie, np. po rozpadzie Związku Radzieckiego akcentowano tam konieczność zapewnienia ochrony pozostawionym w byłych republikach radzieckich mniejszościom ${ }^{83}$. Ważny dla zmian był dokument Spotkania Kopenhaskiego Konferencji w Sprawie Ludzkiego

${ }^{79}$ M. Giedrojć, Problem środków masowego przekazu oraz dostępu do nich mniejszości narodowych i etnicznych w pracach Komisji Mniejszości Narodowych i Etnicznych Sejmu RP, w: Media mniejszości, mniejszości w mediach, pod red. M. Adamik-Szysiak, E. Godlewskiej, Lublin 2014, s. 15-16.

${ }^{80}$ S. Łodziński, Tolerancja czy akceptacja? Etniczne stosunki mniejszościowe w Polsce po 1989 roku, w: Tolerancja i jej granice w relacjach międzykulturowych, pod red. A. Posern-Zielińskiego, Poznań 2004, s. 93.

${ }^{81}$ L.M. Nijakowski, op. cit., s. 113.

${ }^{82}$ Władze pragnęły stworzyć model pamięci jednonarodowej, negując istnienie mniejszości narodowych na terytorium Polski, zob. E. Mironowicz, op. cit., s. 289.

${ }^{83}$ R. Wieruszewski, ONZ-owski system ochrony praw człowieka, w: System ochrony praw człowieka, pod red. B. Banaszaka i in., wyd. 2, Zakamycze 2005, s. 58. 
Wymiaru KBWE (1990), w którym przyjęto zasadę, że przynależność do mniejszości wynika z indywidualnej decyzji jednostki i z tego powodu nie może być szykanowana. Dokument określił też prawa przysługujące mniejszości, a ich respektowanie stało się przepustką do demokracji. Polska z kraju zamkniętego i jednonarodowego stała się sygnatariuszem wielu konwencji i umów międzynarodowych dotyczących ochrony mniejszości narodowych (np. Karty języków regionalnych i mniejszościowych, Konwencji ramowej o ochronie mniejszości etnicznych i narodowych, Konwencji przeciwko dyskryminacji w dziedzinie oświaty UNESCO $)^{84}$ oraz traktatów dwustronnych z państwami sąsiednimi o dobrym sąsiedztwie i przyjaznej współpracy (z Niemcami (1991), z Czechami, Słowacja, Białorusia, Ukraina, Rosją (1992) i Litwą (1994)), które regulowały m.in. wzajemną ochronę mniejszości pochodzących z tych państw ${ }^{85}$.

Inaczej niż w lakonicznych przepisach poprzedniej ustawy zasadniczej, w nowej konstytucji z $1997 \mathrm{r} .{ }^{86} \mathrm{w}$ art. 35 została zapewniona mniejszościom szeroka ochrona ich praw kulturalnych, wolność zachowania i rozwoju własnego języka (także w art. 27), zachowania obyczajów i tradycji oraz rozwoju własnej kultury. Mniejszości uzyskały prawo do tworzenia własnych instytucji edukacyjnych, kulturalnych i instytucji służących ochronie tożsamości religijnej oraz prawo do uczestnictwa $\mathrm{w}$ rozstrzyganiu spraw dotyczących ich tożsamości kulturowej. W art. 54 konstytucji zapewniono im wolność wyrażania swoich poglądów, w art. 58 wolność zrzeszania się i pełnię praw publicznych (także w art. 60). Artykuł 32 podkreśla ich równość wobec prawa, natomiast art. 13 zakazuje istnienia partii politycznych i innych

${ }^{84}$ Polska znajduje się dziś w systemie Narodów Zjednoczonych i Rady Europy. Jest stroną Międzynarodowej konwencji w sprawie likwidacji wszelkich form dyskryminacji rasowej, Konwencji w sprawie zapobiegania i karania zbrodni ludobójstwa, Międzynarodowego Paktu Praw Obywatelskich i Politycznych, Międzynarodowego Paktu Praw Gospodarczych, Społecznych i Kulturalnych, a także Konwencji Praw Dziecka, Konwencji Międzynarodowej Organizacji Pracy nr 111 w sprawie dyskryminacji w zakresie zatrudnienia i wykonywania zawodu.

${ }^{85}$ E. Dynia, Europejski system ochrony praw człowieka a Polska, w: Europejskie standardy ochrony praw człowieka, pod red. E. Dyni, P. Kłaka, Rzeszów 2005, s. 26-27. Traktaty podpisane przez Polskę gwarantowały mniejszościom szeroki wachlarz praw: do posługiwania się własnym językiem, własnej oświaty, własnych mediów, dwujęzycznych oznaczeń w zamieszkiwanych przez nie miejscach, ochrony przed asymilacja, ochrony miejsc pamięci mniejszości i do religii.

${ }^{86}$ Konstytucja Rzeczypospolitej Polskiej z dnia 2 IV 1997 r. (Dz.U. Nr 78, poz. 483 ze zm.). 
organizacji odwołujących się w swoich programach do totalitarnych metod i praktyk działania: nazizmu, faszyzmu i komunizmu, a także tych, których program lub działalność zakłada lub dopuszcza nienawiść rasową i narodowościową.

W wielu ustawach pojawiły się przepisy chroniące prawa mniejszości. Ustawa o wolności sumienia i wyznania z $1989 \mathrm{r} .^{87}$ zagwarantowała każdemu wolność sumienia i wyznania (art. 1 ust. 1). Wprowadziła zakaz dyskryminacji, stanowiąc, że obywatele wierzący wszystkich wyznań i niewierzący mają równe prawa w życiu państwowym, politycznym, gospodarczym, społecznym i kulturalnym (art. 1 ust. 3). Zgodnie z art. 6 ust. 1 nikt nie może być dyskryminowany bądź uprzywilejowany z powodu religii lub przekonań w sprawach religii. Ustawa $z$ dnia 7 września 1991 r. o systemie oświaty ${ }^{88}$ w swej Preambule zaznaczyła, że szkoła i placówka publiczna umożliwia uczniom podtrzymywanie poczucia tożsamości narodowej, etnicznej, językowej i religijnej, a w szczególności naukę języka oraz własnej historii i kultury. Jej rozwinięciem jest Rozporządzenie Ministra Edukacji Narodowej i Sportu z dnia 3 grudnia 2002 r. w sprawie warunków i sposobu wykonywania przez szkoły i placówki publiczne zadań umożliwiających podtrzymywanie poczucia tożsamości narodowej, etnicznej i religijnej uczniów należących do mniejszości narodowych i grup etnicznych ${ }^{89}$. Ustawa z dnia 29 sierpnia 1997 r. o ochronie danych osobowych ${ }^{90} \mathrm{w}$ art. 27 ust. 1 zabroniła, bez zgody osoby, przetwarzania danych wskazujących m.in. na jej pochodzenie rasowe lub etniczne, poglądy polityczne, przekonania religijne lub filozoficzne, przynależność wyznaniową. Ustawa o języku polskim ${ }^{91}$ $\mathrm{w}$ art. 2 podkreśliła, że ochrona języka polskiego nie narusza praw mniejszości narodowych i innych grup etnicznych. Na jej podstawie

${ }^{87}$ Ustawa z dnia 17 V 1989 r. o gwarancjach wolności sumienia i wyznania (Dz.U. Nr 25, poz. 155 ze zm.).

${ }^{88}$ Dz.U. Nr 95, poz. 425.

${ }^{89}$ Dz.U. 2014 Nr 214, poz. 1579. Zgodnie z tym rozporządzeniem nauczanie języka mniejszości, a także jej historii, geografii i kultury kraju pochodzenia mniejszości, organizuje dyrektor szkoły na pisemny wniosek rodziców lub opiekunów prawnych. Nauczanie organizuje się w przedszkolu i w szkole podstawowej, jeżeli zostanie zgłoszonych co najmniej siedmiu uczniów, natomiast w szkole ponadgimnazjalnej czternastu uczniów (§ 5). W przypadku zbyt małej liczby uczniów powinno się zorganizować międzyszkolne zespoły nauczania ( $\$ 6$ ), zob. P. Jurek, Mniejszości narodowe i etniczne w Rzeczypospolitej Polskiej, w: Mniejszości narodowe. Problemy ustrojowo-prawne, pod red. P. Jurka, Wrocław 2005, s. 194-195.

${ }^{90}$ Dz.U. 1997 Nr 133, poz. 883.

${ }^{91}$ Ustawa z dnia 7 X 1999 r. o języku polskim (Dz.U. Nr 90, poz. 999). 
minister spraw wewnętrznych i administracji w 2002 r. wydał rozporządzenie, w którym określono wypadki i granice, w których nazwom i tekstom w urzędach i instytucjach użyteczności publicznej, a także $\mathrm{w}$ środkach transportu publicznego, sporządzanych w języku polskim, mogą towarzyszyć wersje w przekładzie na język obcy ${ }^{92}$. W art. 134 ordynacji wyborczej z 2001 r. ustawodawca zastosował wobec mniejszości narodowych tzw. dyskryminację pozytywna, zwalniając je z obowiązku przekroczenia pięcioprocentowego progu wyborczego w wyborach do sejmu, w celu zapewnienia im stałego w nim przedstawicielstwa (obecnie czyni to w art. 197 Kodeksu wyborczego ${ }^{93}$ ).

Zmiana polityki wobec mniejszości po 1989 r. i zagwarantowanie im szerokiej ochrony w prawie nie zyskały aprobaty części posłów. Prace nad ustawą o ochronie mniejszości narodowych trwały trzynaście lat, co jest swoistym rekordem $\mathrm{w}$ historii sejmu. Trzykrotnie usiłowano uchwalić ustawę ${ }^{94}$. Miara jej kontrowersyjności jest liczba zgłaszanych poprawek (50 poprawek i 25 wniosków mniejszości). Posłowie przeciwni ustawie podnosili, że Polska przede wszystkim powinna troszczyć się o pozostawione na wschodzie mniejszości, a nie o społeczności w niej osiedlone. Kontrowersje wzbudzało wprowadzenie uprawnień dla mniejszości, np. dwujęzycznych oznaczeń, szkolnictwa, posługiwanie się językiem mniejszości w urzędach. Podkreślano, że finansowanie działalności kulturalnej nie powinno obciążać polskiego podatnika, lecz kraje, z których mniejszości pochodzą ${ }^{95}$. Pojawiały się nawet głosy, że ustawa jest owocem spisku mniejszości z krajami ich pochodzenia, niszczącym Polskę. Z mównicy sejmowej padły oskarżenia o antynarodowy charakter ustawy i próbę ponownego rozbicia Polski ${ }^{96}$. Powracano do historii, podając w wątpliwość patriotyzm i lojalność mniejszości wobec państwa polskiego. Wielu posłów domagało się, by bronić przede

${ }^{92}$ Rozporządzenie Ministra Spraw Wewnętrznych i Administracji z dnia 18 III 2002 r. w sprawie wypadków, w których nazwom i tekstom w języku polskim mogą towarzyszyć wersje w przekładzie na język obcy (Dz.U. Nr 37, poz. 349).

${ }^{93}$ Ustawa z dnia 5 I 2011 r. Kodeks wyborczy (Dz.U. Nr 21, poz. 112).

${ }_{94}$ Ostatecznie została ona uchwalona na 95 . posiedzeniu sejmu.

95 A. Kirpsza, Mniejszości narodowe i etniczne w prawie międzynarodowym i polskim, w: Mniejszości narodowe i etniczne, publikacja pokonferencyjna, Kraków 2008, s. 17-18.

${ }^{96}$ Poseł Z. Sosnowski (PSL) oznajmił, że „Klub Parlamentarny PSL nie dawał nigdy zgody i nie da zgody na rozdzieranie Rzeczypospolitej". Poseł J. Czerwiński (RKN) stwierdził, że „ustawa wywoła niepokoje społeczne, w dłuższej perspektywie nawet dezintegrację państwa”. Natomiast poseł M. Kuchciński (PiS) był zdania, że „ustawa skłóci narodowości". Wyrażano obawę, że uprzywilejowanie mniejszości sprawi, iż będą się one izolowały od Polaków. Zob. też A. Kirpsza, op. cit., s. 18. 
wszystkim polskiej godności, suwerenności i racji stanu. Ostatecznie przeważył pogląd, że "w Polsce żyją z nami Ukraińcy i Białorusini, mniejsze grupy Litwinów, Żydów, Słowaków, Niemców, Czechów, Ormian, Tatarów, prawosławni i grekokatolicy oraz chrześcijanie wywodzący się z Reformacji. To nasza niezwykle ważna i wielka spuścizna po dawnej Rzeczpospolitej wielu narodów ${ }^{\prime \prime 97}$. Przyjęto ustawę w przekonaniu, że Polska powinna dać przykład innym państwom europejskim w zakresie ochrony mniejszości, gdyż w przeszłości udzielała schronienia społecznościom prześladowanym w sąsiednich krajach. Stwierdzono, że ochrona mniejszości zaowocuje na zasadzie wzajemności większymi swobodami dla Polaków na obczyźnie ${ }^{98}$.

Brak konstytucyjnej definicji mniejszości ustawodawca uzupełnił w Ustawie z dnia 6 stycznia 2005 r. o mniejszościach narodowych i etnicznych oraz o języku regionalnym ${ }^{99}$. Ustawa ta reguluje sprawy związane z zachowaniem i rozwojem tożsamości kulturowej i języka regionalnego mniejszości, a także sposób realizacji zasady równego traktowania osób bez względu na pochodzenie etniczne oraz określa zadania i kompetencje organów administracji rządowej i samorządowej $\mathrm{w}$ zakresie tych spraw. Zawiera definicje normatywne: zgodnie $\mathrm{z}$ jej art. 2 mniejszość narodowa jest grupą obywateli polskich, która spełnia łącznie następujące warunki: jest mniej liczebna od pozostałej części ludności RP; w sposób istotny odróżnia się od pozostałych obywateli językiem, kulturą lub tradycją; dąży do zachowania swojego języka, kultury lub tradycji; ma świadomość własnej historycznej wspólnoty narodowej i jest ukierunkowana na jej wyrażanie oraz ochronę; jej przodkowie zamieszkiwali obecne terytorium RP od co najmniej stu lat; utożsamia się z narodem zorganizowanym we własnym państwie. Mniejszością etniczną jest grupa, która spełnia łącznie warunki określone dla mniejszości narodowej, lecz z dwiema zmianami: ma świadomość wspólnoty etnicznej oraz nie utożsamia się z narodem zorganizowanym we własnym państwie. Wyróżniono dziewięć mniejszości narodowych (białoruska, czeska, litewska, niemiecka, ormiańska, rosyjska,

${ }^{97}$ R. Drozd, I. Hałagida, Ukraińcy w Polsce 1944-1989. Walka o tożsamość, dokumenty i materiaty, Warszawa 1999, s. 293.

${ }^{98}$ Ustawę krytykowali również przedstawiciele mniejszości narodowych, którzy podkreślali, że wiele jej zapisów, odnoszących się zwłaszcza do dwujęzycznych tablic, nie jest realizowanych, co „spada na sumienie Polaków”, zob. P. Wróblewski, Mobilizacja $i$ konflikt etniczny..., s. 12.

${ }_{99}$ Dz.U. Nr 17, poz. 141 ze zm. (dalej „u.m.n.e.”). 
słowacką, ukraińską i żydowską) oraz cztery etniczne (karaimska, łemkowska, romską i tatarską). Enumeratywne wymienienie mniejszości w ustawie o ochronie mniejszości narodowych i etnicznych wzbudza jednak wątpliwości, czy jest to już zamknięty zbiór.

Osoby spełniające wyżej wskazane kryteria swobodnie decydują o swej przynależności do mniejszości. Ustawa zakazuje stosowania środków mających na celu asymilację osób należących do mniejszości oraz zmieniających proporcje narodowościowe i etniczne na obszarach zamieszkałych przez nie. Przyznała ona prawo do dwujęzyczności, które z punktu widzenia mniejszości jest jednym z najważniejszych czynników służących podtrzymaniu ich własnej tożsamości i podkreśleniu odrębności na płaszczyźnie publicznej. Zgodnie z art. 8 u.m.n.e. mniejszości narodowe mają w szczególności prawo do: (1) swobodnego posługiwania się językiem mniejszości w życiu prywatnym i publicznie, (2) rozpowszechniania i wymiany informacji w języku mniejszości, (3) zamieszczania w języku mniejszości informacji o charakterze prawnym, (4) nauki języka mniejszości lub w języku mniejszości. Mają również prawo do używania i pisowni swoich imion i nazwisk zgodnie z zasadami pisowni języka mniejszości, a w szczególności do ich rejestracji w aktach stanu cywilnego i w dokumentach tożsamości (art. 7 ust. 1 u.m.n.e.). Imiona i nazwiska osób należących do mniejszości zapisane w alfabecie innym niż łaciński podlegają transliteracji. Szczegółowe zasady jej przeprowadzenia określa Rozporządzenie Ministra Spraw Wewnętrznych i Administracji z dnia 30 maja 2005 r. w sprawie sposobu transliteracji imion i nazwisk osób należących do mniejszości narodowych i etnicznych zapisanych w innym alfabecie niż łaciński ${ }^{100}$. Ustawa z dnia 17 października 2008 r. o zmianie imienia i nazwiska ${ }^{101}$ pozbawiła mocy prawnej Ustawę z dnia 15 listopada 1956 r. o zmianie imion i nazwisk. Osoby, którym wcześniej w bezprawny sposób zmieniono imię i nazwisko, mogą powrócić do ich starego brzmienia i pisowni (art. 4 ust. 1 tej ustawy). Nie ponoszą one kosztów związanych z wydaniem decyzji w tym przedmiocie, za wyjątkiem opłat związanych z wydaniem nowych dokumentów. Mniejszościom na mocy art. 9 ust. 1 u.m.n.e. przyznano prawo do używania języka mniejszości jako języka pomocniczego przed organami gminy. Mniejszości mają prawo do: (1) zwracania się do organów gminy w języku pomocniczym w formie

\footnotetext{
${ }^{100}$ Dz.U. Nr 102, poz. 855.

${ }^{101}$ Dz.U. 2009 Nr 220, poz. 1414.
} 
pisemnej lub ustnej, (2) uzyskania na wyraźny wniosek odpowiedzi także w języku pomocniczym $\mathrm{w}$ formie pisemnej lub ustnej (art. 9 ust. 3 u.m.n.e.). Użycie obcego języka w podaniu nie stanowi braku powodującego pozostawienie go bez rozpoznania. Jedynie procedura odwoławcza jest przeprowadzana w języku urzędowym. Ustawa o języku polskim w art. 10 ust. 2 stanowi, że nazwom i tekstom w urzędach i w instytucjach publicznych, a także przeznaczonym do odbioru publicznego oraz w środkach transportu mogą towarzyszyć wersje w przekładzie na język obcy w wypadkach i granicach określonych w rozporządzeniu ministra właściwego do spraw administracji publicznej. Język pomocniczy może być używany jedynie w gminach, w których liczba mieszkańców gminy należących do mniejszości, której język ma być używany jako język pomocniczy, jest nie mniejsza niż $20 \%$ ogólnej liczby mieszkańców gminy i które zostały wpisane do Urzędowego Rejestru Gmin, w których używany jest język pomocniczy. W dniu 25 września 2015 r. sejm przyjął ustawę o zmianie ustawy o mniejszościach narodowych i etnicznych, zgodnie z którą język pomocniczy miał być wprowadzony również w powiatach, w których liczba mieszkańców należących do mniejszości będzie nie mniejsza niż $20 \%$. W ten sposób język pomocniczy (tj. białoruski, litewski, kaszubski) można by było wprowadzić w czterech powiatach. Ustawę zawetował prezydent, argumentując wysokimi kosztami jej realizacji. Przyznanie mniejszościom prawa do używania języka pomocniczego w gminie lub jego braku nie będzie mieć natomiast żadnego związku z wprowadzeniem dodatkowych nazw miejscowości i obiektów fizjograficznych w językach mniejszości lub w języku regionalnym. O prawie tym stanowi art. 12 u.m.n.e., zgodnie z którym tradycyjne nazwy w języku mniejszości mogą być używane obok urzędowych nazw miejscowości, obiektów fizjograficznych oraz obok nazw ulic i placów ustalonych w języku polskim (art. 12 ust. 1 u.m.n.e.). Nazwy te nie mogą być stosowane samodzielnie i występuja po oficjalnej nazwie w języku polskim (art. 12 ust. 5 u.m.n.e.). Moga występować na terenie całej gminy lub w poszczególnych miejscowościach (art. 12 ust. 4 u.m.n.e.). Zgodnie z art. 12 ust. 3 u.m.n.e. nie mogą one nawiązywać do nazw z okresu 1933-1945 nadawanych przez władze Trzeciej Rzeszy Niemieckiej i Związku Socjalistycznych Republik Radzieckich. Są one wprowadzane na terenie gmin, których liczba mieszkańców należących do mniejszości jest nie mniejsza niż 20\%. Jeśli kryterium to nie jest spełnione, wprowadzenie dawnej nazwy zależy od wyniku konsultacji społecznych. Jeżeli za nią opowie się ponad połowa 
mieszkańców danej gminy, wniosek rady gminy pozytywnie opiniuje Komisja Nazw Miejscowości i Obiektów Fizjograficznych (art. 12 ust. 7 u.m.n.e.). Problemem są jednak wandalizm i zamalowywanie dwujęzycznych tablic. W celu realizacji zadań wynikających z ustawy została powołana Komisja Wspólna Rządu i Mniejszości Narodowych i Etnicznych jako organ opiniodawczo-doradczy Prezesa Rady Ministrów ${ }^{102}$.

Ustawa mimo zarzutu, że zakres praw przyznany mniejszościom jest większy niż w konstytucji, dała początek kolejnym regulacjom dotyczącym praw podmiotowych osób należących do mniejszości. Przykładem jest ustawa o radiofonii i telewizji z dnia 29 grudnia 1992 r. ${ }^{103}$, która rozwinęła postanowienia art. 18 u.m.n.e. Zgodnie z jej art. 4 i art. 39b nadawca publiczny jest zobowiązany uwzględnić potrzeby mniejszości narodowych i zezwolić im na rozpowszechnianie swoich programów radiowych i telewizyjnych poprzez przyznawanie koncesji do nadawania tego typów programów. Pojawiło się wiele audycji radiowych i telewizyjnych mniejszości, takich jak radio "Racja”, "Rosyjski głos” w TVP Białystok, cyklicznie nadawane ukraińskie "Telenowyny”, „Schlesische Wochenschau" w OTV w Katowicach ${ }^{104}$. Współczesnym problemem mniejszości jest to, że ich audycje są przesuwane na niekorzystny czas antenowy.

Dowodem zmiany polityki rządu polskiego wobec mniejszości narodowych stał się również spis powszechny w 2002 r., w którym po raz pierwszy od zakończenia II wojny światowej znalazło się pytanie o narodowość. Zostało ono jednak wadliwie sformułowane, gdyż z możliwości: narodowość polska i kraj pochodzenia, ankietowani wybierali pierwsza, kierując się miejscem aktualnego zamieszkania, przez co zostali zaliczeni do Polaków. Wiele też osób, mając trudność w wyborze, podawało podwójną narodowość, np. czechosłowacką, lub określało

${ }^{102}$ Przykładem działań organów publicznych na rzecz wspierania grup mniejszościowych było uwzględnienie struktury narodowościowej przy dokonywaniu nowego podziału administracyjnego Polski na województwa, powiaty i gminy, zob. I Raport dla Sekretarza Generalnego Rady Europy z realizacji przez Rzeczpospolita Polska postanowień Konwencji Ramowej Rady Europy o Ochronie Mniejszości Narodowych, Warszawa 2002, s. 27, dostępny na stronie http://mniejszosci.narodowe.mac.gov.pl/mne/prawo/konwencja-ramowa-rady/raporty-dla-sekretarza/6775,I-Raport-dla-Sekretarza-Generalnego-Rady-Europy-z-realizacji-przez-Rzeczpospolit.html (dostęp: 22 VIII 2016).

${ }^{103}$ Dz.U. 1993 Nr 7, poz. 34.

${ }^{104}$ Programy mniejszości informują o wydarzeniach z przeszłości (np. wysiedlaniu Niemców, obozie pracy przymusowej dla mniejszości niemieckiej, Akcji „Wisła”), by Polacy lepiej je poznali, zob. L.M. Nijakowski, op. cit., s. 133. Efektem audycji jest np. troska o groby zmarłych obcego pochodzenia. 
się jako „autochton", "tutejszy”, "miejscowy”, „obcy" i „prawosławny”. Kolejnym błędem było przyjęcie wyłącznie kryterium językowego jako elementu weryfikującego tożsamość ankietowanego (pytanie: w jakim języku pan/pani rozmawia najczęściej w swoim domu? $)^{105}$, podczas gdy najważniejszym wyznacznikiem tożsamości dla Białorusinów, Ukraińców i Rosjan jest nie język, lecz wyznanie prawosławne. Wielu z nich nie zna już swego rodzimego języka, a nadal przynależy do Kościoła prawosławnego, dzięki czemu zachowuje więź z pierwotną wspólnotą narodową. Brak znajomości języka ojczystego zadecydował o zaliczeniu ich do Polaków. Spis z 2002 r. podawał co najwyżej przybliżoną liczbę osób należących do mniejszości narodowych w Polsce. Za sukces można uznać to, że wiele osób obcego pochodzenia, po latach utajnionego życia w Polsce, zadało sobie pytanie, kim jestem ${ }^{106}$.

Błędy zostały skorygowane i obecnie $\mathrm{w}$ ankiecie spisowej pytania zostały rozszerzone o język, wyznanie, stopień znajomości kultury państwa pochodzenia, przywiązanie do niej, pielęgnowanie tradycji i obyczajów danej mniejszości, czego wyrazem jest uczestnictwo w świętach i wydarzeniach kulturalnych ankietowanej osoby ${ }^{107}$. Powstałe wątpliwości rozwiewa się, przeprowadzając dodatkowo wywiady środowiskowe. Mimo to brak dokładnych danych liczbowych dotyczących wielu grup, np. liczba staroobrzędowców jest szacowana w zależności od źródła na 2 lub 3 tys. osób. W przypadku mniejszości białoruskiej pojawia się duża rozbieżność, gdyż jedne źródła podają liczbę 300 tys., a inne 206 tys. osób ${ }^{108}$. Liczebność mniejszości wynikająca ze spisu jest ważna z punktu widzenia wysokości wsparcia finansowego na jej działalność. Ze względu na to np. przedstawiciele mniejszości niemieckiej zabiegaja, by liczba jej członków w kolejnych spisach powszechnych nie malała ${ }^{109}$.

${ }^{105}$ Mniejszości narodowe i etniczne w procesach transformacji i integracji, pod red. E. Michalik, H. Chałupczaka, Lublin 2006, s. 76.

${ }^{106}$ G. Gudaszewski, Demograficzno-społeczna charakterystyka obywateli polskich deklarujących "narodowość niepolska" w Narodowym Spisie Powszechnym w 2002 roku, w: Mniejszości narodowe w świetle Narodowego Spisu Powszechnego z 2002 roku, pod red. L. Adamczuka, S. Łodzińskiego, Warszawa 2006, s. 85-90.

107 A. Ozyga, Mniejszość ukraińska w Polsce w świetle narodowego spisu powszechnego z 2002 roku, w: Mniejszość polska na Ukrainie. Mniejszość ukraińska w Polsce po 1989 roku, pod red. A. Kasińskiej-Metryki, M. Gołosia, Chełm 2009, s. 78.

108 A. Sadowski, Struktura religijno-etniczna mieszkańców województwa podlaskiego, w: Mniejszości narodowe i etniczne a media elektroniczne..., s. 127, 131.

${ }^{109}$ S. Łodziński, Trauma $i$ władza liczb. Wybrane problemy społecznego odbioru pytania o "Narodowość" w Narodowym Spisie Powszechnym z 2002 roku, w: Mniejszości narodowe w Polsce w świetle Narodowego Spisu Powszechnego..., s. 184-185. 
Powszechne jest przekonanie, że oficjalne dane zaniżają liczebność mniejszości w Polsce, co wynika nie tylko z błędów w pytaniach w spisach powszechnych, ale też z zatajania narodowości przez wiele osób powołujących się na prawo do ochrony danych osobowych, które obawiają się ujawnienia narodowości w swoim środowisku lokalnym i trwałego zamknięcia ich w kręgu danej mniejszości. Współcześnie wielu Białorusinów, Litwinów, Rosjan oraz Ukraińców nie chce być postrzeganych przez pryzmat kraju swego pochodzenia. Chca jak najszybciej wtopić się w polskie społeczeństwo i ulec asymilacji. Różne są przyczyny tego zjawiska: Białorusini, polonizując imiona i nazwiska swoich dzieci, liczą na to, że to ułatwi im karierę (zmieniają nazwiska kończące się na -uk, tak by kończyły się na -ski oraz imiona białoruskie na występujące w kalendarzu katolickim, w ten sposób Wiera staje się Wanda, Zinaida - Zosia, Alosza - Aleksym, a Bazyli - Bogdanem, co określa się jako zjawisko ukrywania stygmatu $)^{110}$; Litwini i Rosjanie obawiają się niechęci Polaków ze względu na politykę państw ich pochodzenia; Ukraińcy chcą być identyfikowani z polskością, której kultura w ich opinii przewyższa ich rodzimą.

Asymilacji sprzyja też dyskryminacja mniejszości. Są pewne przejawy nietolerancji na tle wspólnej historii, zwłaszcza na pograniczach, gdzie mniejszość mieszka w skupiskach i łatwo ustalić, "kto jest kto”. Rozpamiętywanie przeszłości i sporządzanie rachunku krzywd wyrządzonych Polsce przez inne społeczności (tzw. dyskryminacja historyczna) ciągle jeszcze są żywe dla niewielkiej grupy Polaków ${ }^{111}$.

Zachowanie i rozwój tożsamości narodowej i etnicznej mniejszości determinowane są również przez czynniki pozainstytucjonalne, w tym głównie demograficzne. Niż demograficzny dotyczy w równym stopniu rodzin polskich, jak i mniejszości, a dzieci urodzone w rodzinach mieszanych często przejmują kulturę dominującą i utożsamiają się z Polską. W przypadku Białorusinów i Niemców, silnie zintegrowanych ze społeczeństwem polskim, polonizacja następuje już w kolejnych pokoleniach. Do spadku liczebności mniejszości może przyczynić się ich trudna sytuacja materialna. Mniejszości zamieszkują głównie tereny Polski Wschodniej, gdzie poziom życia i warunki ekonomiczne znacznie odbiegają od reszty kraju, co może skłonić członków mniejszości

${ }^{110}$ E. Czykwin, Białoruska mniejszość narodowa. Problem asymilacji w kontekście stygmatu społecznego, w: Białorusini, pod red. T. Zaniewskiej, Warszawa 2010, s. 39.

${ }^{111}$ S. Łodziński, Tolerancja czy akceptacja..., s. 92-93. 
do wyjazdu z Polski. Opuszczają Polskę też Niemcy, mimo że mają najlepszą sytuację materialną wśród mniejszości. Przeciwwagą dla zmniejszania się liczebności mniejszości w Polsce może być imigracja ${ }^{112}$.

\section{Imigracja do Polski}

W latach dziewięćdziesiątych XX w. przyjeżdżali do Polski w poszukiwaniu pracy imigranci z ubogich państw (Bułgarii, Rumunii, Albanii, Armenii, Wietnamu, Iraku, Chin i Somalii) oraz azylanci polityczni (Czeczeni). Trudno określić wielkość tej pierwszej migracji, zarobkowej, gdyż wiele osób wielokrotnie przekraczało granice Polski, często fałszując dokumenty lub wjeżdżając pod zmienionym nazwiskiem ${ }^{113}$. Nielegalnych imigrantów nie można było deportować, ponieważ nie mieli dokumentów ${ }^{114}$. W większości dla tych osób przyjazd do Polski kończył się rozczarowaniem, gdyż nie spełniała ona ich oczekiwań, głównie bytowych. Stwarzali też problemy Polakom. Stąd ich decyzja wyjazdu do Europy Zachodniej. Niektórzy, jak Albańczycy i Wietnamczycy, zachowują jednak nadal silne więzi, tworzą zwarte społeczności, są wierni endogamii małżeńskiej, przez co tworzą zalążek dla rozwoju przyszłych mniejszości narodowych ${ }^{115}$. Nie można wykluczyć, że kolejne pokolenia tych grup emigrantów będą ubiegać się w przyszłości o taki status, o ile nie rozproszą się $\mathrm{w}$ społeczeństwie polskim i nie ulegną $\mathrm{w}$ nim asymilacji ${ }^{116}$. Asymilacja jest możliwa, bowiem w miejscach, w których występują znaczne skupiska tej mniejszości, jak w województwie

${ }^{112}$ I Raport dla Sekretarza Generalnego Rady Europy..., s. 27.

${ }^{113}$ P. Lechowski, Migracje Romów rumuńskich, s. 10, http://www.romowie.com/ instytut/io2007_lechowski.pdf (dostęp: 12 I 2015).

${ }_{114}$ A. Wojtaszak, Problemy migracji zewnętrznej na Pomorzu Zachodnim po 1989 roku, w: Polityka i mniejszości narodowe..., s. 186.

${ }^{115}$ J. Brzozowski, K. Pędziwiatr, Sytuacja migrantów w Małopolsce: między integracja, asymilacja, separacją i marginalizacja, http://biuletynmigracyjny.uw.edu.pl/48-czerwiec-2014/ sytuacja-imigrantow-w-malopolsce-miedzy-integracja-asymilacja-separacja-i-marginali (dostęp: 12 XII 2016). Wietnamczycy tworzą hermetyczną grupę, są zorganizowani i utrzymują ścisłe kontakty ze soba, co ułatwia im Towarzystwo Społeczno-Kulturalne Wietnamczyków, zob. A. Jakuczek, Migranci wietnamscy w Polsce, w: Mniejszości narodowe i etniczne, pod red. J. Kihl i in., Kraków 2008, s. 84.

${ }^{116}$ Polska po Francji i Niemczech jest w Europie trzecim co do liczebności krajem migracji ludności z Wietnamu. Uznaniu jej za mniejszość sprzyja to, że tworzy hermetyczne środowisko, zob. A. Jakuczek, op. cit., s. 79. 
mazowieckim, widoczna jest niechęć Polaków do nich z powodów ekonomicznych (konkurencja dla miejscowych kupców) ${ }^{117}$.

Dziś imigranci niechętnie przyjeżdżają do Polski. Stanowią zaledwie 0,5\% ludności, co jest najniższym wskaźnikiem wśród krajów $E^{118}$. Nawet gdy w 2013 r. widocznie wzrosła migracja do Polski, bijąc dotychczasowe rekordy, w rankingach atrakcyjności imigracyjnej byliśmy na końcu światowej i europejskiej statystyki. Na niewielkie zainteresowanie imigrantów Polską składa się wiele przyczyn, głównie niższy poziom gospodarczy niż krajów zachodnich oraz tendencja do przemieszczania się ludności ze Wschodu na Zachód. Rzadkością jest, by rodzina z Europy Zachodniej zamieszkała w Polsce. Trudno jest w naszym kraju utrzymać uchodźców, którzy mogliby w przyszłości tworzyć nowe mniejszości. Traktują oni Polskę jako kraj tranzytowy, nagminnie uciekając z przeznaczonych dla nich ośrodków do państw zachodnich ${ }^{119}$. Nawet ci, którzy deklarują w dokumentach Polskę, myślą o niej jako kraju tranzytowym do Europy Zachodniej ${ }^{120}$. Polska jako członek UE pozostaje wciąż atrakcyjnym państwem pod względem warunków bytowych dla przybyszów ze Wschodniej Europy, o podobnej kulturze i mentalności, zwłaszcza z Ukrainy, którzy otrzymując zgodę na pracę lub na pobyt stały na obszarze RP, mogą zwiększać liczebność „wschodnich” mniejszości narodowych ${ }^{121}$. Jednak otwarcie rynków w UE dla emigrantów z państw byłego ZSRR sprawia, że motywowani chęcią poprawy standardu życia coraz chętniej osiedlają się w innych krajach Unii, omijając Polskę ${ }^{122}$.

${ }^{117}$ Ibidem, s. 89.

${ }^{118}$ W spisie powszechnym ujawniły się grupy: Francuzów, Amerykanów, Włochów i Bułgarów, co wskazuje na polityczny charakter definicji legalnej.

119 A. Redelbach, Natura praw człowieka - strasburskie standardy ich ochrony, Toruń 2001, s. 199.

${ }^{120}$ Nawet uchodźcy nie chca mieszkaćw Polsce, http://natemat.pl/138969, nawet-uchodzcy-nie-chca-mieszkac-w-polsce-placza-gdy-dowiaduja-sie-ze-to-nie-niemcy-polska-da-im-bilet-powrotny (dostęp: 9 VIII 2015).

${ }^{121}$ Imigracja osób z państw mniejszości narodowych zapobiega ich całkowitemu zaniknięciu w naszym kraju. Grupy osób, które zadeklarowały się w spisie powszechnym z 2011 r. jako cudzoziemcy, tj. osoby nieposiadające obywatelstwa polskiego, to $57,5$ tys. osób ( $0,15 \%)$. Większość z nich pochodzi z Rosji $(31,4 \%)$ i z Ukrainy $(22,5 \%)$. Od czasu spisu niektórzy cudzoziemcy uzyskali obywatelstwo polskie i dołączyli do mniejszości narodowej, pochodzącej z ich kraju, zob. G. Gudaszewski, Identyfikacje etniczne w Narodowym Spisie Powszechnym Ludności i Mieszkań z 2011 roku, w: Mniejszości narodowe i etniczne w Polsce w świetle Narodowego Spisu Powszechnego Ludności z 2011 roku, pod red. S. Łodzińskiego, K. Warmińskiej, G. Gudaszewskiego, Warszawa 2015, s. 101.

122 J. Lalak, Problemy zwiazane zatrudnianiem cudzoziemców na terytorium Rzeczypospolitej Polskiej, w: Mniejszość polska na Ukrainie..., s. 172. 
Także zatem dla osób z Europy Wschodniej Polska jest coraz częściej krajem tranzytowym niż docelowym. Obecnie nasz kraj musi rozstrzygnąć kwestię przyjęcia uchodźców z ogarniętej wojną Syrii. Uchodźcy ci może stworzą nową mniejszość muzułmańską w naszym kraju w dalekiej przyszłości. Czy jednak osiedlą się tutaj na stałe?

Przyjazd do Polski emigrantów z sąsiednich państw wschodnich długi czas utrudniały uciążliwe procedury administracyjne związane z podjęciem pracy i wysokie opłaty manipulacyjne. Obowiązywały one, ponieważ obawiano się o miejsca pracy w doświadczającej wysokiego bezrobocia Polsce. Sytuacja zmieniła się po wejściu naszego kraju do UE. W 2008 r. w obliczu masowej migracji Polaków do UE i, co za tym idzie, braku rąk do pracy na rynku polskim procedury zostały uproszczone - to jednak nie wpłynęło na masowe decyzje o pozostaniu w Polsce na stałe ${ }^{123}$. Największą grupę pracowników migracyjnych tworzą Ukraińcy, najczęściej zatrudniani przy pracach sezonowych, którzy po sezonie wracają na Ukrainę. Wojna między Ukrainą i Rosją spowodowała, że Ukraińcy, którzy wcześniej pracowali w Rosji, teraz ponownie podejmują pracę $w$ Polsce. Niewykluczone, że wzrośnie też liczba chętnych do osiedlenia się tu na stałe. Należy także pamiętać o polityce UE dotyczącej migracji zarobkowej. W Zielonej Księdze w sprawie podejścia Unii Europejskiej do zarządzania migracjami zarobkowymi określono, że kraje członkowskie, oferując pracę, muszą kierować się następującą kolejnością zatrudnienia: własny obywatel, obywatel UE, a następnie pozostałe osoby. Wysokie bezrobocie w Polsce sprawia, że obecnie nie prowadzi się u nas aktywnej polityki imigracyjnej ${ }^{124}$. Sa obawy, by z powodu nadmiernej migracji zarobkowej nie załamał się rynek pracy w Polsce. Można zatem oczekiwać, że w przyszłości tylko w niewielkim stopniu zwiększy się liczebność mniejszości ukraińskiej i białoruskiej. Czy nie należy zatem uznać także osób nieposiadających polskiego obywatelstwa, np. osiedlonych w Polsce emigrantów zarobkowych, za członków mniejszości? Wtedy łatwiej byłoby zachować liczebność wielu mniejszości narodowych, a pracowników migracyjnych

${ }^{123}$ Częściej w Polsce zostają pracownicy z bardziej odległych państw, takich jak Chiny, Mongolia, Wietnam. Po upływie okresu zezwolenia na pracę nadal pozostawali w Polsce, tworząc szarą strefę, głównie z powodu wysokich kosztów podróży powrotnej, zob. M. Okólski, Polska jako kraj imigracji - wprowadzenie, w: Transformacja nieoczywista. Polska jako kraj imigracji, pod red. A. Górnego, I. Grabowskiej-Lusińskiej, M. Lesińskiej, M. Okólskiego, Warszawa 2010, s. 46-47.

${ }^{124}$ Ibidem, s. 76. 
uchronić przed asymilacją z Polakami. Migranci pracowniczy z krajów wschodnich, przybywając do Polski, nie uzupełnią jednak w pełni ubytku mniejszości ${ }^{125}$.

\section{Sytuacja mniejszości w 2015 r.}

Obecna sytuacja społeczno-polityczna mniejszości narodowych w Polsce jest zróżnicowana. Pomimo że po 1989 r. mniejszość niemiecka ponownie została uznana przez państwo polskie, co pozwoliło jej na pełen rozwój własnego życia kulturowego (powstawanie niemieckich towarzystw, szkół, mediów, prawo do własnego przedstawiciela w sejmie), obecnie nie brakuje głosów, by ograniczyć te prawa. Część ugrupowań, m.in. Powiernictwo Polskie, pragnie odebrać Niemcom przyznane im przywileje, co jest skutkiem asymetrii między ich prawami w Polsce a prawami Polaków mieszkających w Niemczech ${ }^{126}$. Przed II wojną światową Polacy mieli tam status mniejszości narodowej i korzystali z wielu praw, m.in. do własnej oświaty i mediów oraz do nauki języka polskiego. Na mocy dekretu Göringa z 1940 r. utracili ten status i związane z nim prawa. Po wojnie władze Niemiec utrzymały taki stan. Traktat sąsiedzki z 1991 r. nie przywrócił Polakom statusu mniejszości narodowej, choć rząd polski przyznał go zamieszkującym w Polsce Niemcom ${ }^{127}$.

Utrudniony rozwój dotyka też mniejszość litewska, co wiąże się z łamaniem praw mniejszości polskiej na Litwie. Ograniczenie w tym kraju jej praw językowych i prawa do własnego szkolnictwa powoduje m.in., że w Polsce zamalowywane są litewskie tablice (np. w Puńsku), a pomniki litewskie niszczone. Mniejszość rosyjska, mimo iż niewielka

${ }^{125}$ Sposobem na zwiększenie liczby mniejszości narodowych mogłoby być uznanie za nie Kaszubów, Łemków i Ślązaków, co wywołuje duże kontrowersje, zob. S. Łodziński, Czyje prawa chronić, w: Polityka i mniejszości narodowe..., s. 40.

${ }^{126}$ Powiernictwo Polskie zaapelowało do premiera D. Tuska: „mamy nadzieję, iż polski rząd bez zbędnej zwłoki przedstawi Sejmowi projekty nowelizacji odpowiednich ustaw, w szczególności ordynacji wyborczej, ustawy o mniejszościach narodowych i etnicznych oraz o języku regionalnym, które będą stanowczą odpowiedzią na nieprzychylne Warszawie kroki z Berlina” ("Gazeta Prawna”, http://prawo.gazetaprawna. pl/artykuly/362411, powiernictwo-polskie-do-premiera-odebrac-prawa-mniejszosciniemieckiej.html (dostęp: 12 XII 2016).

${ }^{127} \mathrm{~W}$ art. 20 traktatu określa się ich jako „osoby posiadające niemieckie obywatelstwo, które są polskiego pochodzenia" (Traktat sąsiedzki między Rzecząpospolitą Polską a Republiką Federalną Niemiec o dobrym sąsiedztwie i przyjaznej współpracy z 17 VI $1991 \mathrm{r}$. (Dz.U. 1992 Nr 14, poz. 56). 
i rozproszona ${ }^{128}$, pada ofiarą licznych stereotypów. Niektórzy Polacy traktują ją jako "niechcianą pamiątkę po byłym ZSRR”, a nawet kojarzą z zaborcami, co sprawia, że Rosjanie zatajają swe pochodzenie. Mniejszość ukraińska domaga się zadośćuczynienia za przymusowe przesiedlenia, co poróżnia polskie społeczeństwo. Część osób jest zdania, że Ukraińcy dzięki przesiedleniu uzyskali szanse na awans cywilizacyjny, opuścili bowiem ubogie ziemie wschodnie, by zamieszkać na lepiej rozwiniętym Zachodzie. Ich zdaniem Akcja Wisła znajduje moralne usprawiedliwienie w związku z terrorystyczną działalnością UPA i możliwością wybuchu wojny polsko-ukraińskiej ${ }^{129}$.

Podobne żądania kieruje do państwa polskiego mniejszość żydowska. Domaga się ona restytucji swego mienia, cmentarzy, synagog, jesziw (szkół religijnych). Kwoty roszczeń są niebagatelne: wynoszą ok. 200 mld zł, co stanowi 15-20\% majątku narodowego Polski. Kontrowersje wywołuje fakt, że niektóre instytucje żydowskie domagają się zwrotu majątku po ofiarach holocaustu dokonanego przez Niemcy, które powinny być adresatem tych roszczeń. Część Polaków uważa takie roszczenia od Polski za "cios wymierzony w nasz kraj" i czynienie go współwinnym wybuchu wojny. Problemy polsko-żydowskie dotyczą również odpowiedzialności Polaków za pogromy ludności żydowskiej po wojnie.

Przedstawiciele mniejszości białoruskiej zostali porzuceni przez Aleksandra Łukaszenkę uznającego ich za zdrajców. Ich los spoczywa w rękach polskich. Sami Białorusini nie uważają się za przedstawicieli narodu białoruskiego, lecz za "tutejszych" i "miejscowych", osiedlonych od wieków na ziemiach polskich.

W najlepszej sytuacji znajduje się obecnie mniejszość czeska w Zelowie. Czesi są jednym z najbardziej lubianych narodów w Polsce, co przekłada się na życzliwy stosunek do ich mniejszości. Z kolei mniejszość słowacka w Polsce zanika, gdyż wielu jej przedstawicieli wyjeżdża do dawnej ojczyzny lub do większych miast w Polsce, np. Krakowa czy Warszawy.

Mniejszości narodowe i etniczne wzbogacają kulturę polską i gwarantują jej różnorodność, a przy okazji kształtują postawy Polaków. Bezpośredni kontakt $\mathrm{z}$ różnymi narodowościami wyrabia umiejętność obcowania z innymi w życiu społecznym i zawodowym, uczy tolerancji

${ }^{128}$ L.M. Nijakowski, op. cit., s. 66.

${ }^{129}$ Mniejszość ukraińska domaga się ponadto powrotu do pierwotnej pisowni nazwisk, które zostały spolonizowane po przeprowadzeniu Akcji Wisła, zob. Mniejszości narodowe i etniczne w Polsce w świetle Narodowego Spisu Powszechnego Ludności..., s. 298. 
i zrozumienia. Zamknięcie na obcość, jak w poprzedniej epoce, zawsze skutkuje izolacją kraju, a co za tym idzie, wzrostem poglądów nacjonalistycznych ${ }^{130}$. Mniejszości narodowe w Polsce pełnią rolę pomostu pomiędzy Polską a innymi krajami, służąc budowaniu dobrych relacji sąsiedzkich ${ }^{131}$. Uczą też patriotyzmu - zgodnie z zasada, że nie ma "swoich", jeżeli nie ma też „obcych".

Problemem w Polsce jest zjawisko tzw. regionalizacji mniejszości, oznaczające, że większość społeczeństwa nie ma pełnej wiedzy na temat mniejszości narodowych i etnicznych, a problemy mniejszości zamykają się w granicach lokalnych ( $w$ tzw. małych ojczyznach ich osiedlenia) ${ }^{132}$. Mimo wspierania rozwoju kultury mniejszości przez państwo pojawia się niebezpieczeństwo jej zaniku wobec oddziaływania na nią polskiej kultury narodowej oraz kultury globalnej. Mniejszości utraciły swój wiejski, zamknięty charakter, a młodzi niechętnie kultywują stare tradycje i obyczaje. Mniejszości narodowe żyją zatem pomiędzy integracją separacja, asymilacją i marginalizacją.

\section{Podsumowanie}

Podjęte w niniejszym artykule rozważania pozwalają stwierdzić, że:

1. PRL odrzuciła model państwa wielonarodowego, jaki tradycyjnie obowiązywał w Polsce, na rzecz państwa jednolitego narodowo i prowadziła politykę eliminowania mniejszości ze społeczeństwa polskiego. W efekcie działań państwa sztucznie stworzono wrażenie, że w Polsce nie ma mniejszości narodowych i etnicznych.

2. III RP przejęła dziedzictwo historyczne otwarcia się na obcych, przyjmując za podstawowy cel swej polityki wobec mniejszości zachowanie ich tożsamości narodowej i etnicznej. Współczesne gwarancje prawne stabilizują pozycję mniejszości w Polsce.

${ }^{130}$ A. Grzymała-Kazłowska, Konstruowanie "innego": wizerunki imigrantów w Polsce, Warszawa 2007, s. 51.

${ }^{131} \mathrm{Z}$ drugiej strony zagwarantowanie im praw na równi z prawami Polaków może zwiększyć świadomość i solidarność narodu polskiego. Twierdzi się, że naród zmuszony do rezygnacji z części praw i z części terytorium na rzecz obcej ludności ma większe poczucie solidarności, tożsamości i wspólnoty niż żyjący w etnicznej izolacji.

${ }^{132}$ A. Budyta-Budzyńska, op. cit., s. 25. Regionalizacja jest skutkiem tego, że mniejszości jest mało, stąd niewielu Polaków zna osobiście przedstawicieli mniejszości narodowych obecnych w naszym kraju. Sprzyja temu tendencja do zawyżania liczebności niektórych mniejszości narodowych, np. Żydów, lub jej zaniżania, np. Białorusinów. 
3. Ogólna tendencja starzenia się społeczeństwa prowadzi do zmniejszenia się liczebności mniejszości. Temu zjawisku nie zapobiegnie imigracja.

4. Atrakcyjność kultury polskiej i światowej dla mniejszości sprawia, że możliwy jest zanik kultury mniejszości narodowych, mimo wsparcia finansowego i organizacyjnego państwa polskiego. Czynniki pozaprawne mogą więc ograniczać podstawowy cel polityki RP wobec mniejszości. W obliczu zagrożenia przekształcenia się Polski w kraj jednolity etnicznie powinna ona prowadzić działania służące zachowaniu mniejszości na jej obszarze, tak by po mniejszościach nie pozostały, jak sądzi wielu, tylko cmentarze, dzieła sztuki, muzea, stroje ludowe i pamiątki architektoniczne ${ }^{133}$. Pamięć o mniejszościach jest tym ważniejsza, że Polacy mają tendencję do zapominania osiągnięć i tradycji innych grup etnicznych żyjących na ich terytorium ${ }^{134}$.

\section{NATIONAL MINORITIES IN POLAND - A HISTORICAL AND LEGAL OUTLINE}

\section{Su m mary}

Poland has a centuries long tradition of being a tolerant country, manifested as well by the symbolic official name: Poland of Both Nations (1569-1795). Poles, Lithuanians and numerous national minorities lived side by side in the territory of the Polish Republic and today their descendants are Polish citizens. During the time of partitions Poles maintained strong national community feelings, which subsequently helped in the building of the Second Polish Republic. The reborn Poland was again a multi-national state, however, certain nationalistic feelings started to emerge. After World War II as a result of the extermination of minorities and mass resettlements, the historical multinational character disappeared and the minimal set of rights granted to minorities in the Constitution of 1952 had led to their ethnic exclusion. After March 1968, the rights of minorities had become drastically limited. This continued till the Third Republic of Poland when the policy of the Communist authorities promoting the building of Poland for the Poles had been abandoned and the new government pursued to preserve and protect national and ethnic minorities. Today, members of minorities have the same rights as ethnic Poles, and their rights are guaranteed in the Constitution of 1997 and other legislative acts

${ }^{133}$ Mniejszości narodowe i etniczne w Polsce..., s. 11. W przedmowie tej publikacji zwraca się także uwagę na przeniesione do kuchni polskiej potrawy, takie jak pierogi ruskie, chłodnik litewski, barszcz ukraiński, karp po żydowsku, pieczeń po cygańsku, golonka po bawarsku, tatar i sos tatarski, włoszczyzna czy kawa po turecku.

${ }^{134}$ L.M. Nijakowski, op. cit., s. 102. 
including the most important one, i.e. the Act on National and Ethnic Minorities and the Regional Language of 2015, which defines national and ethnic minorities and determines the competences of the State bodies in the area of enforcing minorities rights. These solutions have secured Poland an opinion of a model state when it comes to the protection of minorities rights. There are nine national minorities officially recognised in Poland. Each has a different situation resulting from historical conditions, circumstances, national stereotypes, relationship with the States of their origin and the position of the Polish minority in this State. Two main problems which minorities in Poland are facing today is their shrinking populations and threats to their culture from the Polish and global cultures. Immigration might be a possible remedy but low economic attractiveness of Poland fails to attract new immigrants which means that in the future Poland may practically become a one-nation state.

Keywords: national minority - ethnic minority - minority rights - minority policy of the state - minority population 